\title{
Slope Belts of Paleouplifts Control the Pore Structure of Organic Matter of Marine Shale: A Comparative Study of Lower Cambrian Rocks in the Sichuan Basin
}

\author{
Pengfei Wang, ${ }^{1,2}$ Chen Zhang, ${ }^{2,3}$ Aoran Liu ${ }^{10},{ }^{4,5}$ Pengfei Zhang, ${ }^{6}$ Yibo Qiu, ${ }^{6}$ Xin Li, \\ Shanshan Yu, ${ }^{7}$ Shuqing Yao, ${ }^{1}$ Sanyi Liu, ${ }^{1}$ and Zhenxue Jiang ${ }^{2,3}$ \\ ${ }^{1}$ Geoscience Documentation Center of China Geological Survey, Beijing 100083, China \\ ${ }^{2}$ State Key Laboratory of Petroleum Resources and Prospecting, China University of Petroleum, Beijing, China \\ ${ }^{3}$ College of Geoscience, China University of Petroleum, Beijing, China \\ ${ }^{4}$ Hebei Key Laboratory of Strategic Critical Mineral Resources, Hebei GEO University, Shijiazhuang 050031, China \\ ${ }^{5}$ College of Geosciences, Hebei GEO University, Shijiazhuang 050031, China \\ ${ }^{6}$ Research Institute of Exploration and Development, Sinopec Shengli Oilfield Company, Dongying 257000, China \\ ${ }^{7}$ China National Offshore Oil Corporation Research Institute, Beijing 100028, China \\ Correspondence should be addressed to Aoran Liu; aoranliu@cug.edu.cn
}

Received 20 January 2021; Accepted 4 June 2021; Published 29 June 2021

Academic Editor: Henrik Drake

Copyright (C) 2021 Pengfei Wang et al. This is an open access article distributed under the Creative Commons Attribution License, which permits unrestricted use, distribution, and reproduction in any medium, provided the original work is properly cited.

\begin{abstract}
Extensive exploration of the marine shale of the Niutitang Formation in south China has been conducted. However, exploration and development results have varied considerably in different areas. For example, the Niutitang shale in Jingyan City (Southwestern Sichuan Basin) produces a large amount of gas with a long period of stable production. In contrast, most development wells in the Niutitang shale in Chongqing City do not produce gas. Scanning electron microscopy images showed that the organic matter $(\mathrm{OM})$ pore development in the Niutitang shale in Jingyan is abundant, large in size, and are well connected. In contrast, OM pores in the Niutitang shale in Chongqing are rarely observed. OM pore development of the Jingyan and Chongqing shales is mainly controlled by thermal maturity as shown by equivalent vitrine reflectance determinations. The moderate thermal maturity has resulted in the development of a large number of OM pores in the Niutitang shale in Jingyan, whereas the high thermal maturity of the Niutitang shale in Chongqing has led to the destruction of most of the OM pores. Due to the existence of ancient uplift, the shale was buried shallowly in the process of hydrocarbon generation evolution, and the shale avoided excessive thermal evolution and retained appropriate thermal maturity. In the Jingyan area, due to its location near the central uplift in the Sichuan Basin, the Niutitang shale deposited nearby avoided excessive evolution, and a large number of OM pores were retained in the reservoir.
\end{abstract}

\section{Introduction}

The Lower Cambrian Niutitang Formation contains highly to overly mature organic-rich black marine shales with high TOC content and type I kerogen that is widely distributed in south China $[1,2]$. However, their exploration and development potential vary significantly between different areas. For example, the Niutitang shale in Chongqing City (south China) has only a short stable production of gas, low gas volumes, or even no gas production at all in some wells, and hence no successful development [3, 4]. However, successful exploration and development of the Niutitang shale has been made in Jingyan City in Sichuan Province (south China), where commercial gas has been successfully produced from the JinYel well [1]. The gas produced from shale wells can reach $2.3 \mathrm{~m}^{3} / \mathrm{t}$, with the daily gas output of $6.0 \times 10^{4} \mathrm{~m}^{3} / \mathrm{d}$ [5].

Successful exploration and development of the Niutitang shale has been made in Yichang City of Hubei Province (south China) by the China Geological Survey, where commercial gas has been successfully produced from the wells 


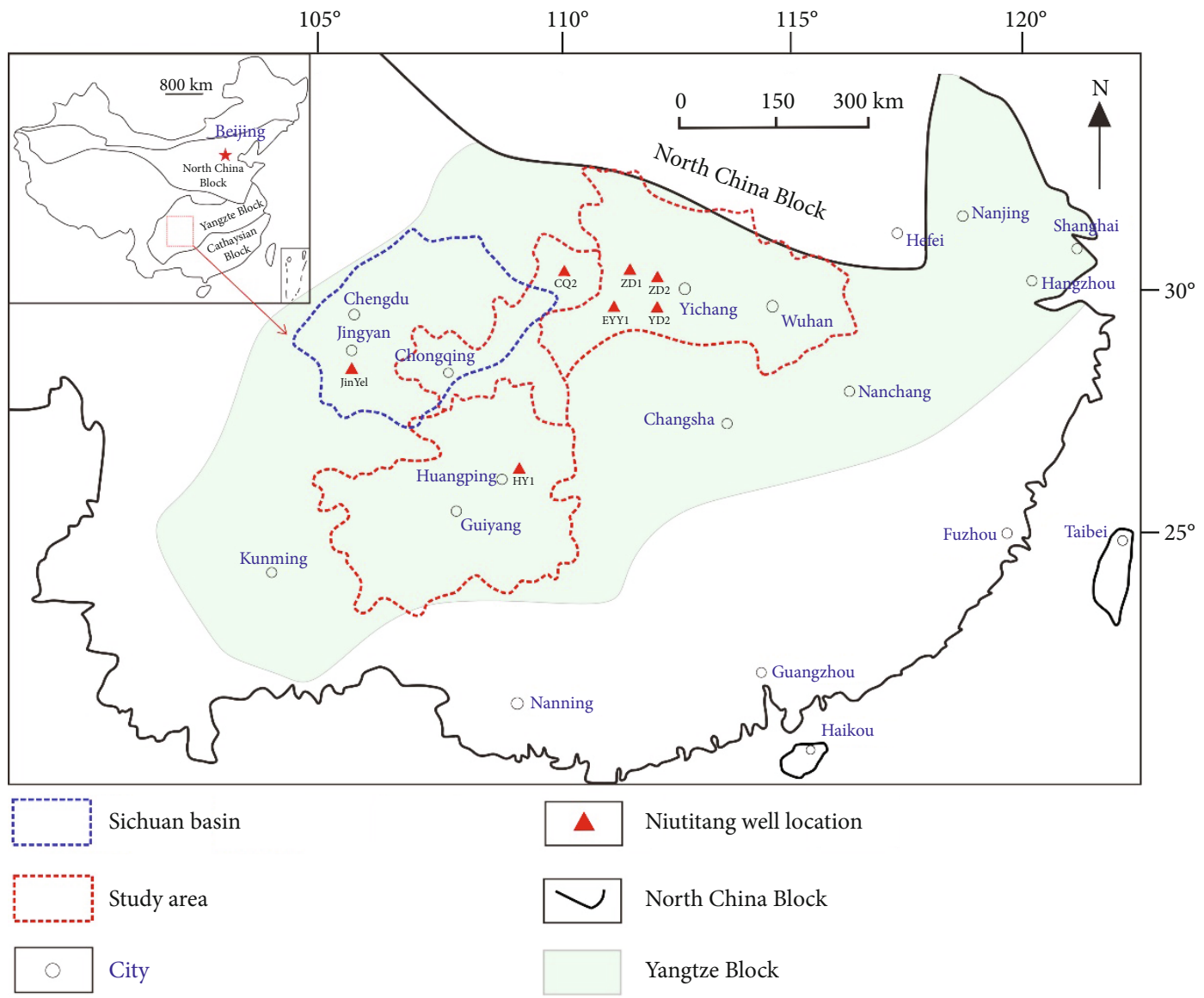

FIgUre 1: Position of the study area and Niutitang shale well distribution in Chongqing, Sichuan Basin, Hubei Province, and Guizhou Province.

EYY1 and ZD2 [6, 7]. In the EYY1 well, for example, the thickness of the Niutitang shale with gas total hydrocarbon exceeding $1.0 \%$ is $77 \mathrm{~m}[7,8]$. The gas from shale wells reaches $2.2 \mathrm{~m}^{3} / \mathrm{t}$ with a daily gas output of $7.8 \times 10^{4} \mathrm{~m}^{3} / \mathrm{d}$ [5]. Furthermore, the Niutitang shale in Jingyan also showed commercial gas with a daily gas output of6.0 $\times 10^{4} \mathrm{~m}^{3} / \mathrm{d}[4]$.

Successful exploration and development of the Niutitang shale has also been made in Southern Guizhou (south China), where commercial gas has been successfully produced from the HY1 well $[9,10]$. The HY1 well has a gas content of $1.3 \mathrm{~m}^{3} / \mathrm{t}$ [11].

Micro- to nanometer size pores have been shown to be important storage spaces for hydrocarbon gas in shale [12, 13]. Previous studies show that different micro- to nanometer-sized pore structures present different gas storage capacities [14-16]. In particular, OM pores have been demonstrated to be effective storage spaces for gas $[17,18]$. For shale reservoirs, OM pores can impact the exploration and development potential by providing space for gas to be stored and for gas to flow through [19-21].

OM pore development is affected by a variety of rock parameters, including TOC content, mineralogy, kerogen type, and thermal maturity $[12,13]$. An abundant TOC content provides the source material for OM pore development [1]. Brittle minerals, such as silica, can relieve the pressure from the overlying rock on OM pores and can provide support for the preservation of OM pores $[14,15]$. Kerogen, bitumen, and pyrobitumen have distinct physical and chemical properties and can cause different styles of OM pore development [19]. Too high or too low thermal maturity is also not conducive for the development of OM pores [16].

Many studies have suggested that a number of marine shales in southern China generally have high TOC contents on average $(>2.0 \%)$, high siliceous mineral content, and the same kerogen type (type I), but the thermal maturity of different formations of marine shales varies considerably [18-21]. For example, several researchers have compared shales of the Lower Silurian Longmaxi Formation $\left(2.0 \%<R_{\mathrm{o}}<3.0 \%\right)$ with those of the Lower Cambrian Niutitang Formation in Chongqing, the former of which have produced commercial gas [22, 23]. They concluded that high thermal maturity is the key reason resulting in the low gas content and low production in the Niutitang shale in Chongqing [1, 13, 14, 24-26].

Burial history and hence thermal maturity have a strong control over OM porosity development and petroleum generation [27, 28]. The OM pore evolution and petroleum generation are also closely related to the tectonic evolution $[29,30]$. 


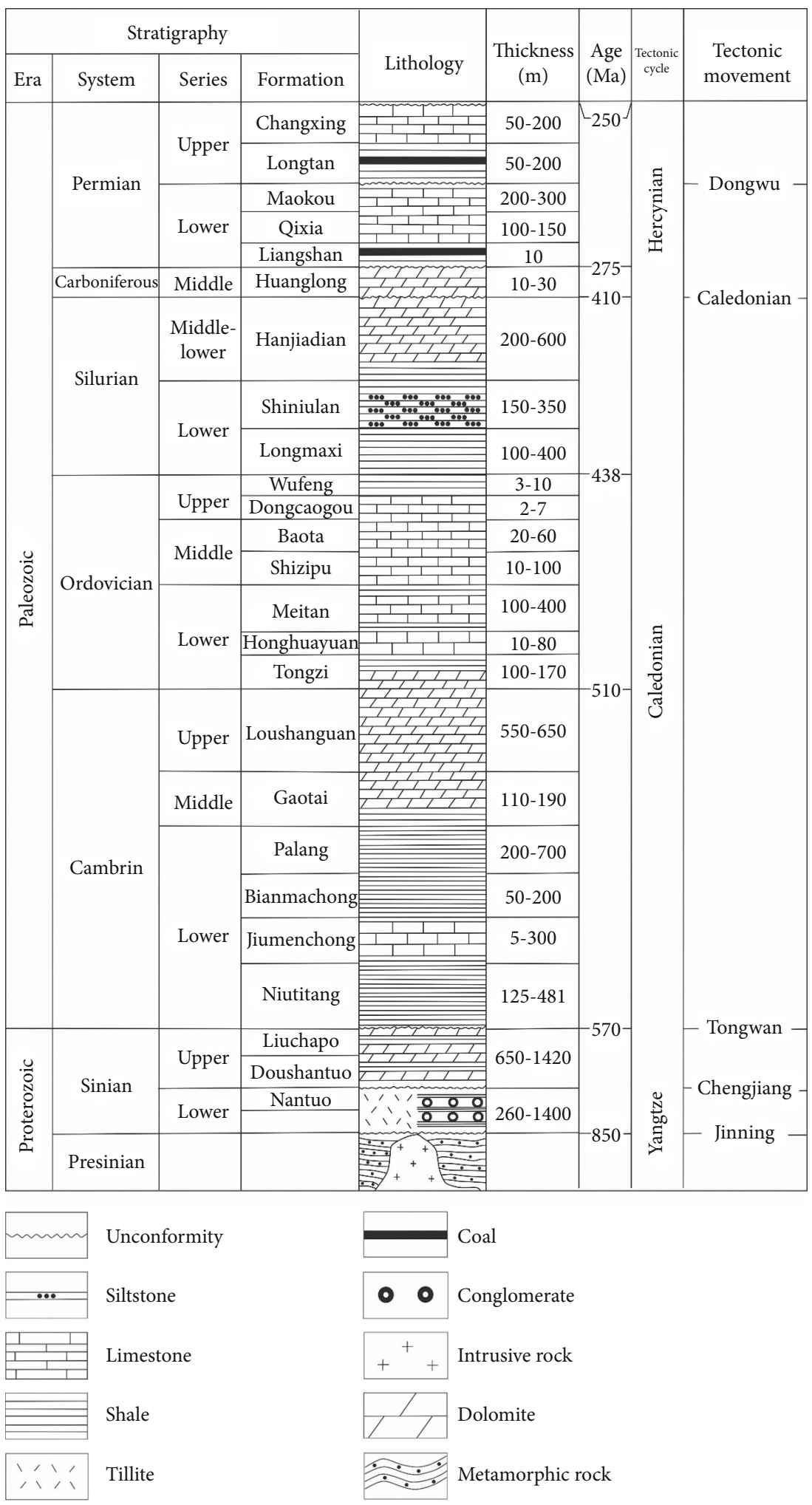

FIGURE 2: Stratigraphic sections of the study area. This figure was revised from Ref. [33].

This study used samples of the Niutitang shale from wells in the Chongqing and Jingyan areas (southwestern Sichuan Basin) as research objects (Figures 1 and 2). Combined with the regional structural characteristics, the shales of Niutitang
Formation in the Huangping area in southern Guizhou and Yichang area in western Hubei are compared. The OM pore characteristics of Niutitang shale in different exploration and development blocks in southern China were clarified, and 

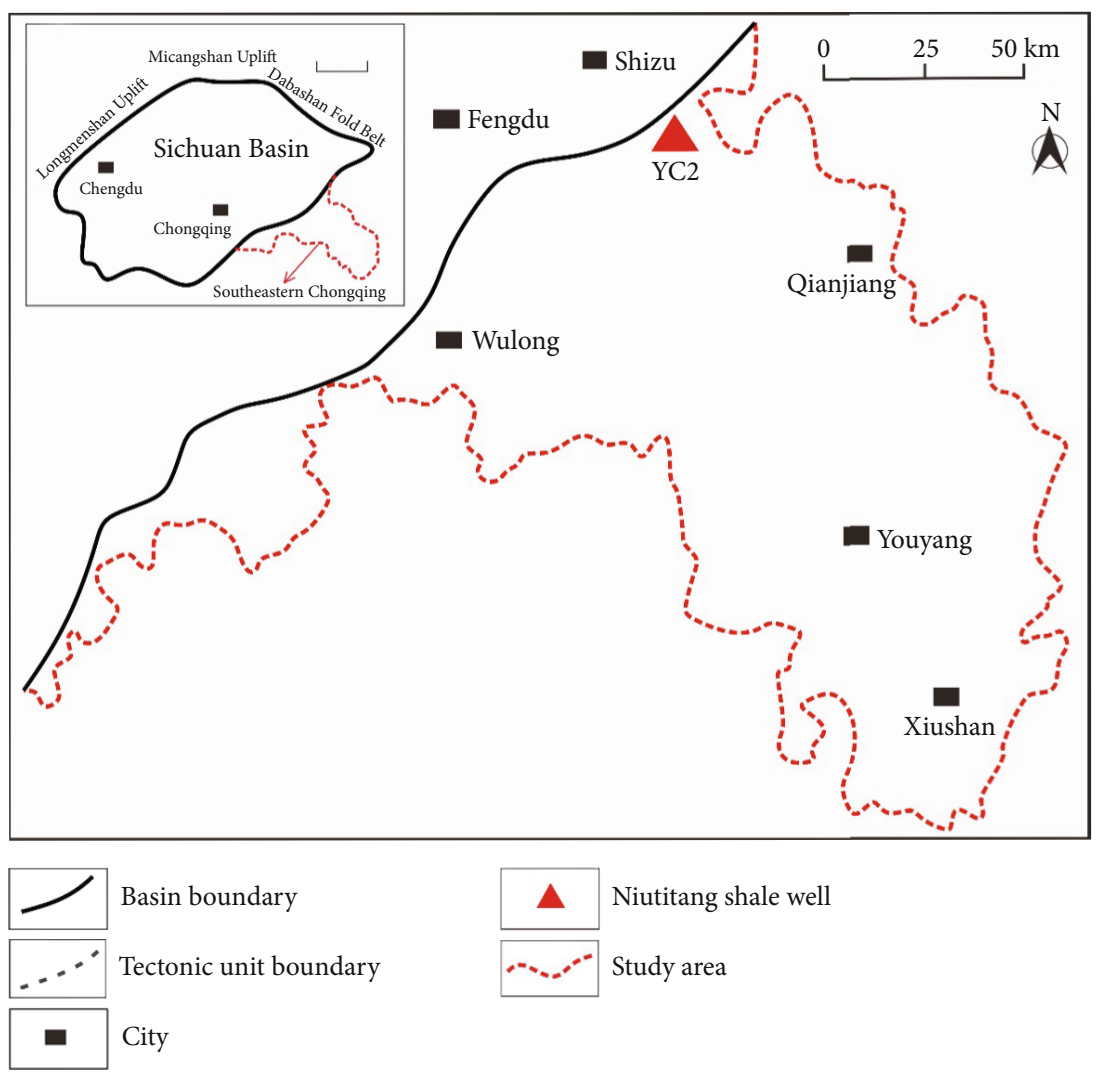

(a)

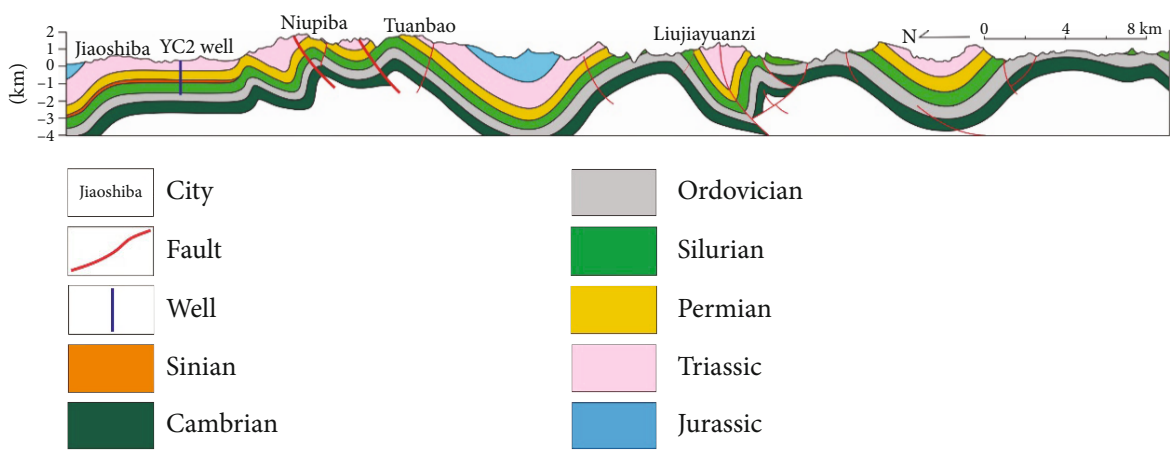

(b)

FIgURE 3: Plane and section structure of southeastern Chongqing. This figure was revised from Refs. [28, 36].

finally, the special structural characteristics were proposed as exploration targets for the efficient exploration and development of ancient marine shale in south of China.

\section{Geological Setting}

2.1. Chongqing Area. The Chongqing area is located in the southeastern margin of the Sichuan Basin, south China, and structurally, it is located in the southeastern part of the Yangtze Platform (Figure 3). This area has experienced three main tectonic stages since the Late Mesoproterozoic: continental margin oceanic crust changing to continental crust during the Late Proterozoic to Silurian, continental expansion during the Devonian to Middle-Late Triassic, and
Pacific plate subduction and Indian plate collision during the Mesozoic to Cenozoic [31, 32].

During the Early and Late Paleozoic, the Yangtze Platform experienced many large-scale transgression events, forming four sets of black shales during the Cambrian, the Upper Ordovician to the Lower Silurian, the Lower Permian, and the Upper Permian (Figure 2). The Niutitang shale in Chongqing was deposited during the Early Cambrian, when extensional activities resulted in the disintegration of southern Pangea and the expansion of the oceanic crust, leading to large-scale transgression [34]. The exploration target in the Chongqing area is the base section of the Niutitang Formation, which is mainly thick, black carbonaceous shale with high TOC content and siliceous minerals [35]. There is also some silty shale and a small amount of siliceous shale. These 


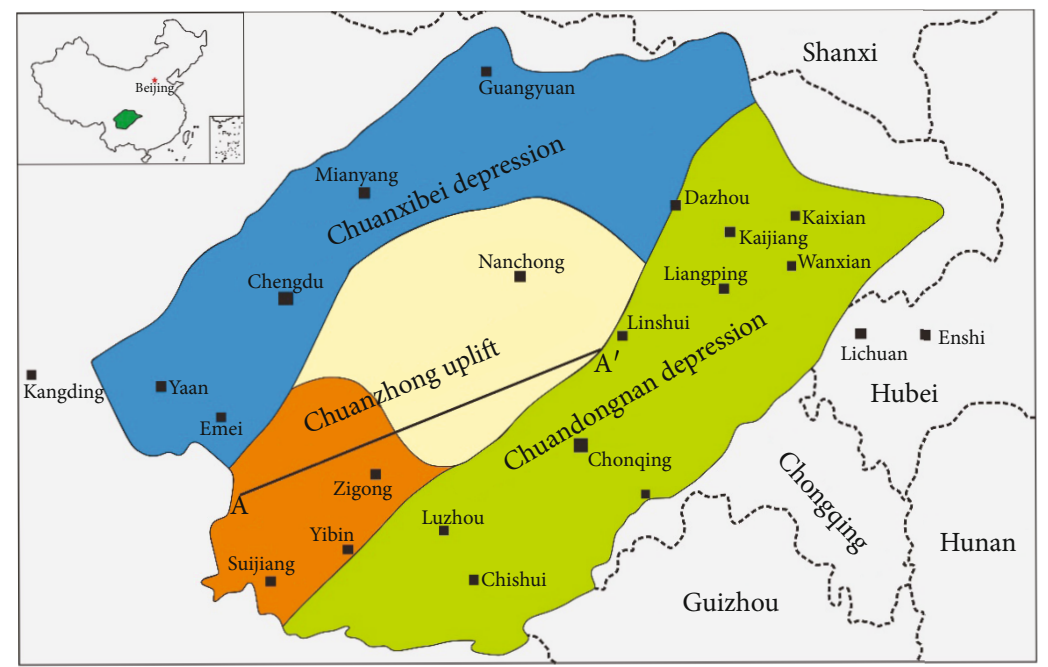

(a)

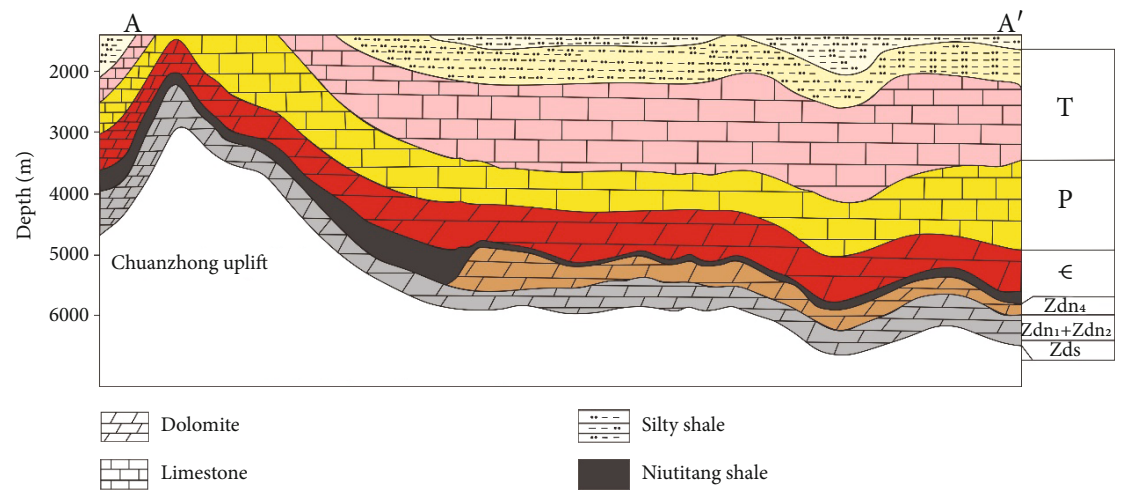

(b)

Figure 4: Plane and section structure of the Chuanzhong Uplift of Sichuan Basin. This figure was revised from Ref. [25].

TABLE 1: TOC content, Eq- $R_{0}$, and mineral composition of reservoir parameters from the Chongqing and Jingyan samples for FIB-SEM.

\begin{tabular}{|c|c|c|c|c|c|c|c|c|c|c|c|}
\hline \multirow{2}{*}{ Sample } & \multirow{2}{*}{ Well } & \multirow{2}{*}{ Area } & \multirow{2}{*}{ Formation } & \multirow{2}{*}{ Depth (m) } & \multirow{2}{*}{ TOC (\%) } & \multirow{2}{*}{$\mathrm{Eq}-R_{\mathrm{o}}(\%)$} & \multicolumn{5}{|c|}{ Mineral (\%) } \\
\hline & & & & & & & Quartz & Feldspar & Calcareous & Clay & Pyrites \\
\hline$\# 1$ & CQ2 & Chongqing & Niutitang & 1149 & 2.86 & 3.54 & 49.6 & 14.7 & 15.9 & 17.6 & 2.2 \\
\hline$\# 2$ & JinYe1 & Jingyan & Niutitang & 3296.2 & 2.36 & 2.79 & 33.1 & 21 & 5.1 & 37.1 & 3.7 \\
\hline
\end{tabular}

sediments were deposited on a deep-water shelf under mainly reducing conditions [28-30].

2.2. Jingyan Area. The Jingyan area is located at the southwestern margin of the Sichuan Basin, between the large Weiyuan and Tieshan anticlines (Figure 4). In the Early Cambrian, medium-deep-water shelf deposition developed in the Jingyan area, and the water column gradually deepened from NW to SE [28].

The Niutitang Formation deposited in the Jingyan area is characterized by unequal interbedding of gray-dark gray shale, silty shale, and gray-dark gray calcareous litharenite, gray siltstone, and argillaceous siltstone [3]. From bottom to top, the black shale mainly changes into an interlayer between black shale and dark gray and between gray argillaceous siltstone and gray siltstone, and the interlayer is increased [4]. In the middle and upper part, there is a small amount of lenticular gray or siliceous nodules and a small amount of pyrite. The mineralogy is mainly quartz and clay, with minor carbonate minerals [3, 4, 20, 21].

\section{Focused Ion Beam Scanning Electron Microscopy (FIB-SEM)}

FIB-SEM analysis for the observation of OM pores was conducted using a FEI HELIOS NanoLab 650 (FEI Corporation, United States). Before that, samples were ground, argon ion polished, and carbon sprayed to increase electrical conductivity (Table 1). The secondary electron emission technology of FIB-SEM was also used to further identify OM pore characteristics. This technology can create bright lights around the pores, highlighting the surface 


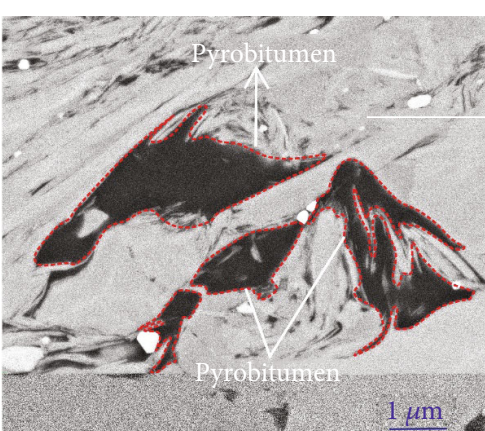

(a)

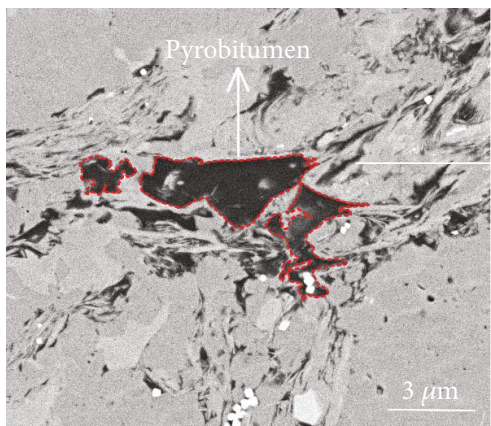

(c)

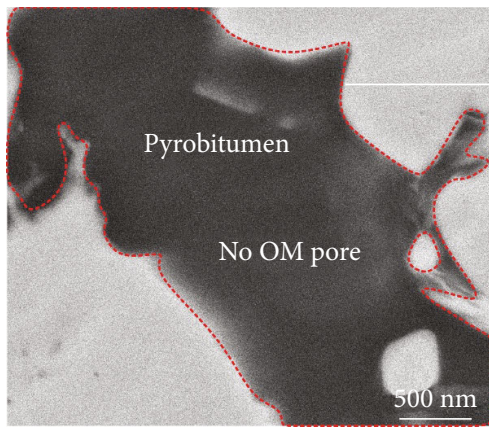

(e)

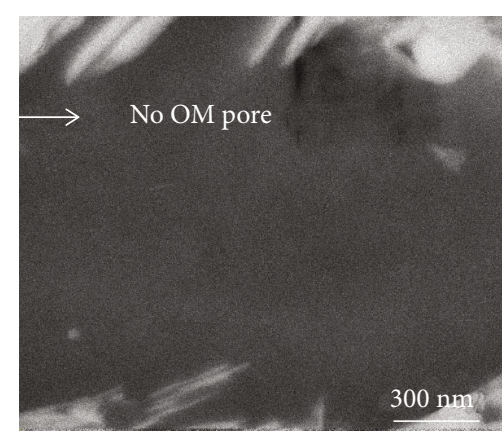

(b)

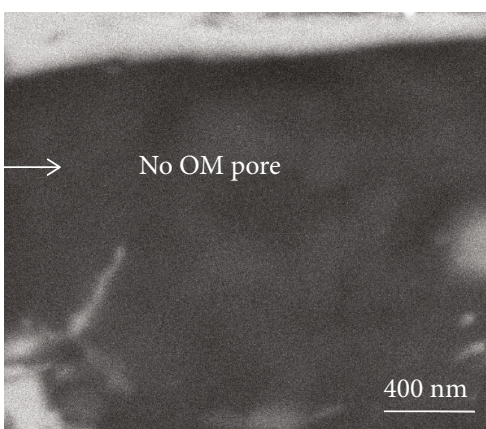

(d)

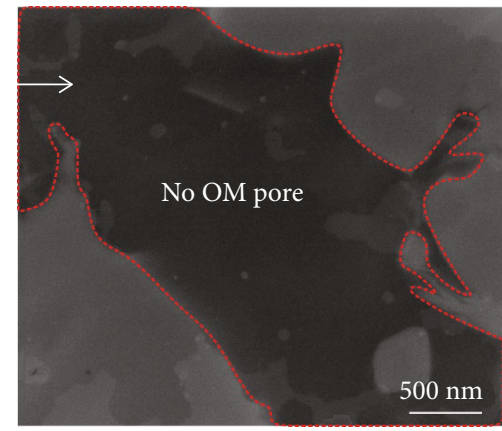

(f)

FIGURE 5: No OM pore in the pyrobitumen of Chongqing samples (CQ2 well, $1149 \mathrm{~m}$ ). The secondary electron technique can highlight the pores in a circular layer, making them easy to identify. If no highlight is found in the pyrobitumen, there is no OM pore. The secondary electron technique proves that there is no OM pore in the pyrobitumen of the Chongqing sample.

morphology of OM pores and making them easier to identify even under low resolution.

\section{Results}

There are no OM pores in the pyrobitumen of the Chongqing samples, as indicated by SEM imaging (Figure 5). The secondary electronic imaging was used to highlight the morphology of any smaller-scale inner structure in these shale samples; however, none was observed in the pyrobitumen of the Chongqing samples (Figure 6). This further proves that there are no OM pores in the Chongqing samples. However, under the FIB-SEM, the pyrobitumen in the Niutitang shale in Jingyan shows a large number of OM pores (Figures 7 and 8), which are characterized by round and oval shapes, uniform distribution, and a large pore size.

\section{Discussion}

5.1. Comparison with Jingyan and Chongqing Areas. A large number of OM pores can not only increase the adsorption capacity for gas but also be conducive to the effective flow of gas in a shale reservoir by enhancing the connectivity $[2,17$, 26]. This may be one reason why the Niutitang shale produces commercial gas in Jingyan but not in Chongqing (Figures 5-9).

Rock parameters of the Niutitang shale from Jingyan were compared with those from Chongqing. As shown in Table 2, these shale samples share very similar reservoir characteristics such as average TOC content, mineral composition, and kerogen type, but they have very different Eq- $R_{\mathrm{o}}$. The Niutitang shale in Jingyan with abundant OM pores has anEq- $R_{\mathrm{o}}$ of less than $3.0 \%$, while the Niutitang shale in Chongqing with almost no OM pores has anEq- $R_{\mathrm{o}}$ larger than $3.0 \%$. It reveals that the formation and preservation of OM pores are likely controlled by thermal maturity $[1,26,27]$. 


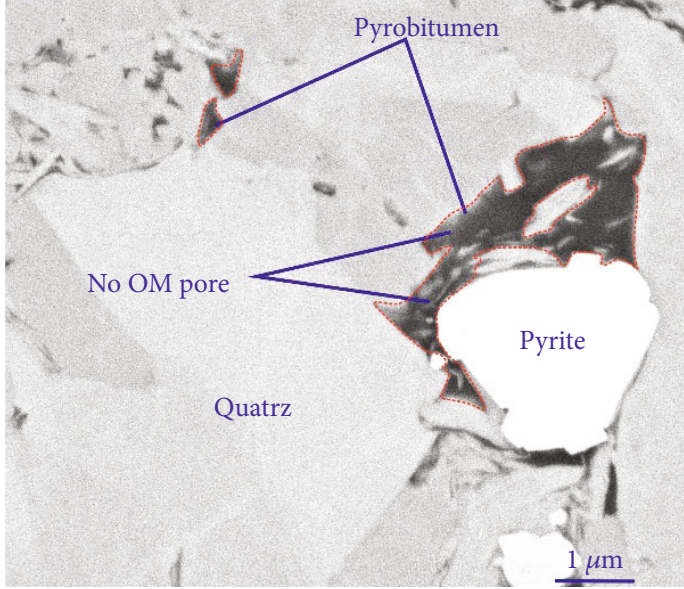

(a)

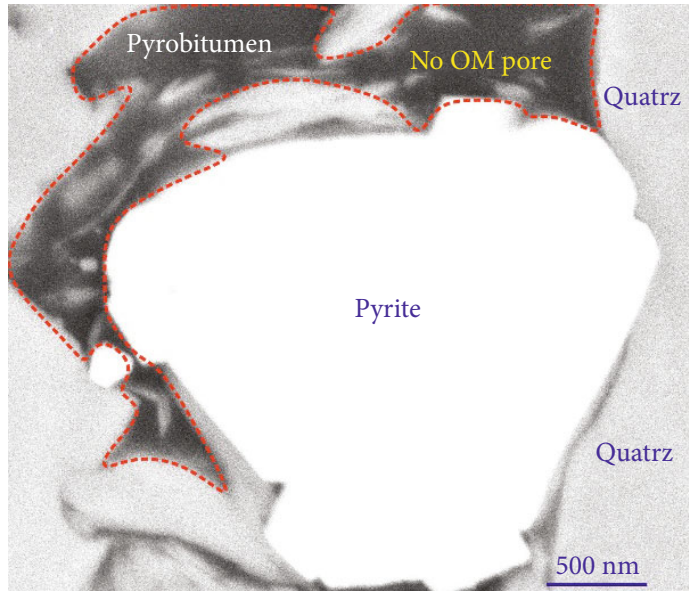

(c)

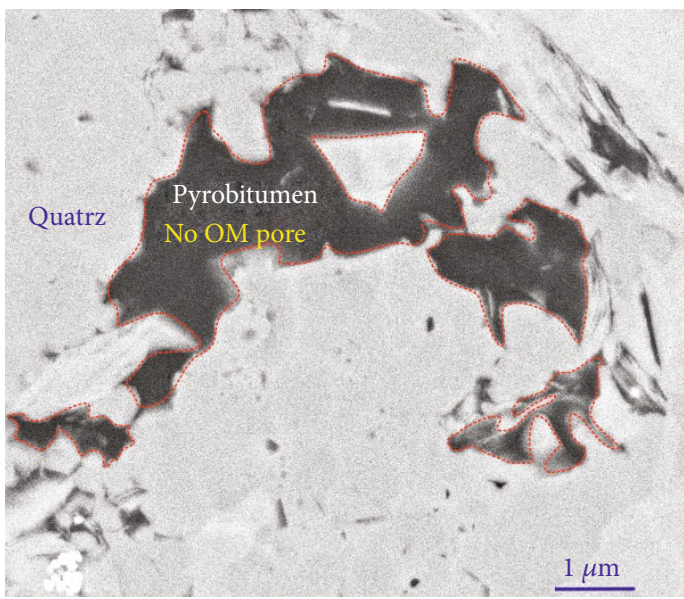

(e)

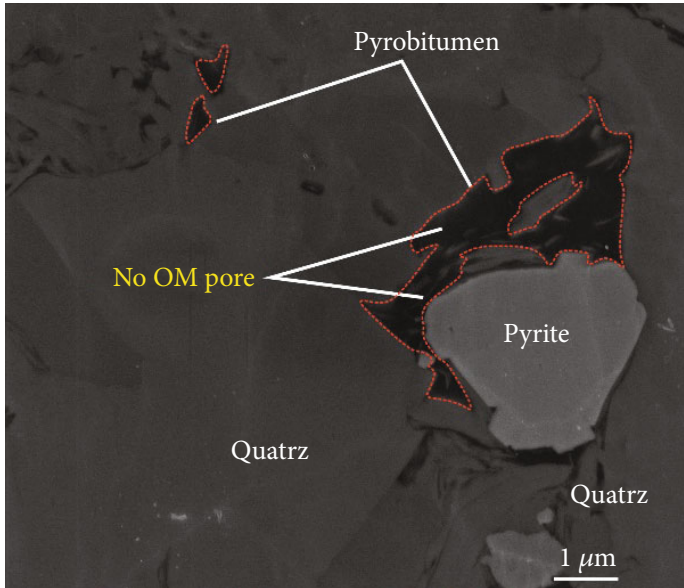

(b)

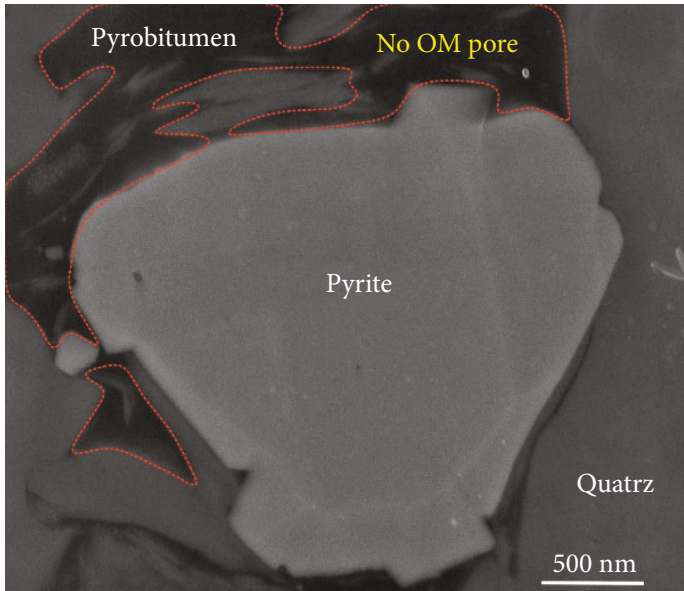

(d)

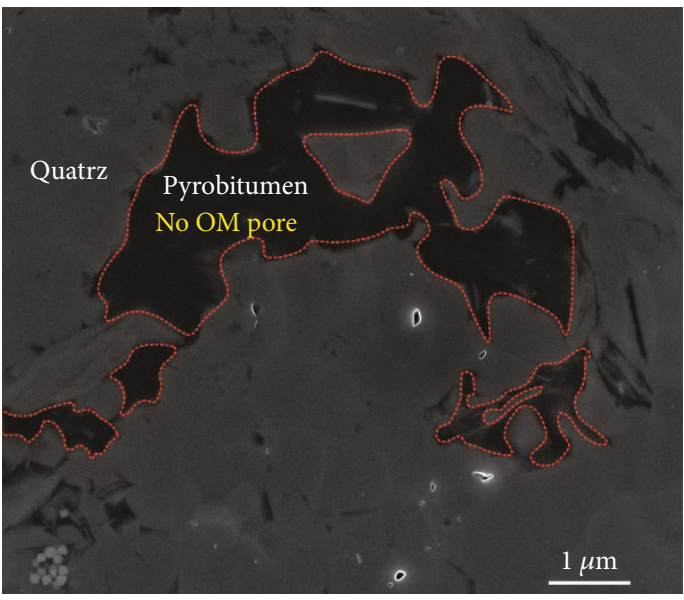

(f)

FIgURE 6: No OM pore in the pyrobitumen of Chongqing samples (CQ2 well, $1149 \mathrm{~m}$ ). The secondary electron technique can highlight the pores in a circular layer, making them easy to identify. If no highlight is found in the pyrobitumen, there is no OM pore. The secondary electron technique proves that there is no OM pore in the pyrobitumen of the Chongqing sample.

The thermal evolution and the associated OM pore generation and hydrocarbon potential in shale are closely related to the tectonic evolution of the study areas $[37,38]$. For the Chongqing study area, the maximum paleoburial depth of the Niutitang shale is $8000 \mathrm{~m}$, corresponding to an Eq- $R_{\mathrm{o}}$ exceeding 3.5\% (Figure 10). A large number of OM pores in the pyrobitumen were destroyed due to excessive thermal evolution, resulting in the loss of hydrocarbon gases in shale. 


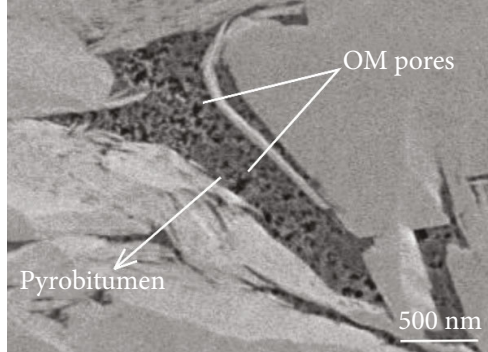

(a)

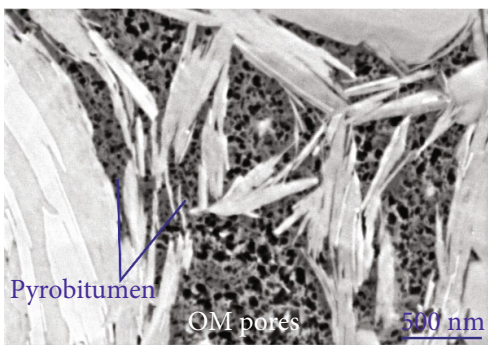

(d)

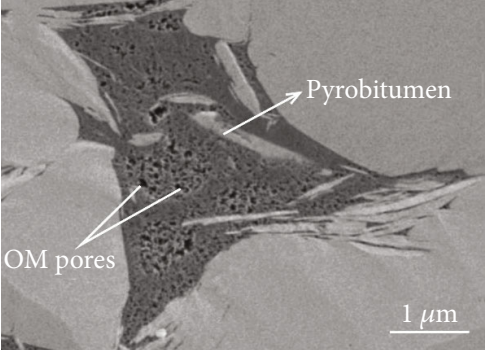

(b)

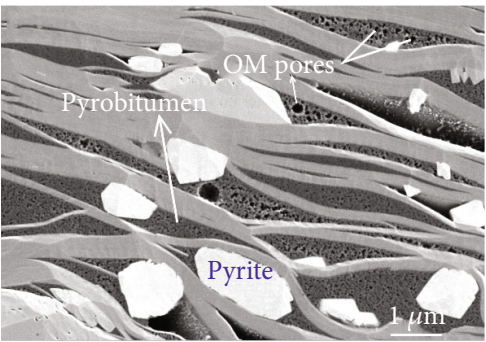

(e)

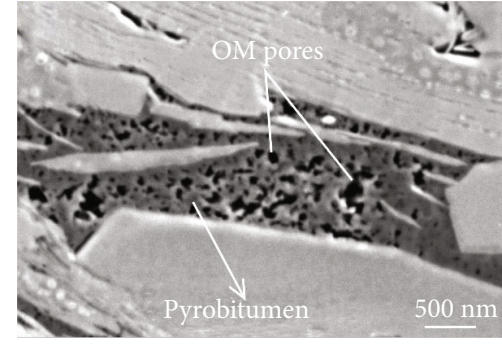

(c)

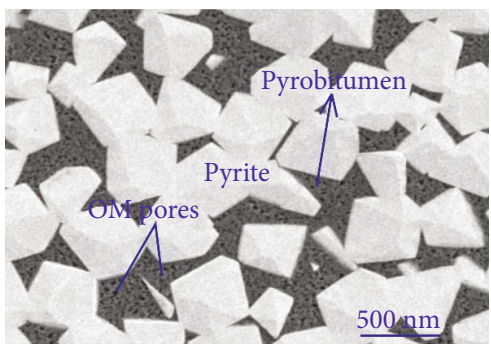

(f)

Figure 7: A large number of OM pores in the pyrobitumen of Jingyan samples (JinYe1 well, $3296.2 \mathrm{~m}$ ) are shown. (a-e) OM pores in the pyrobitumen of the mineral matrix. (f) The pyrobitumen with OM pores in pyrite particles.

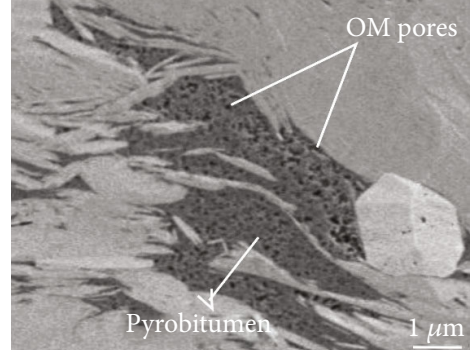

(a)

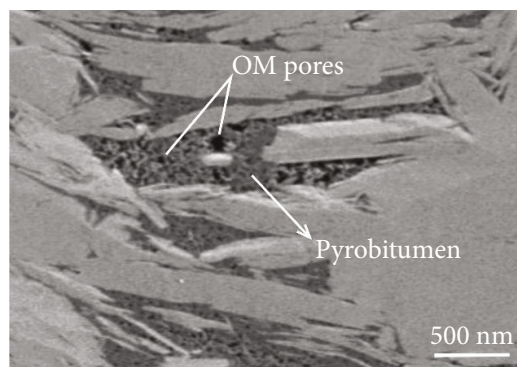

(d)

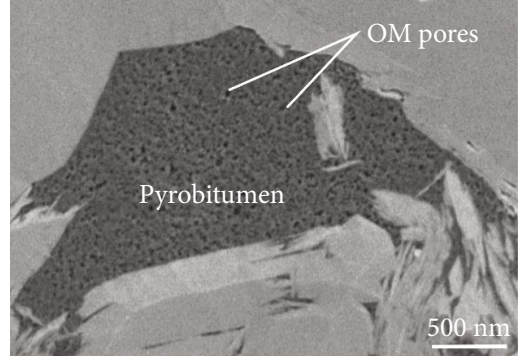

(b)

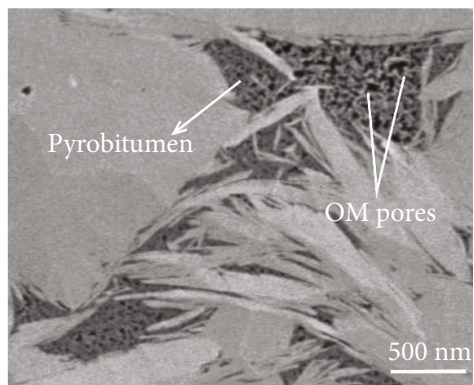

(e)

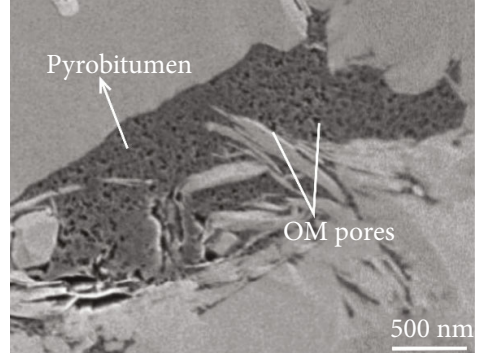

(c)

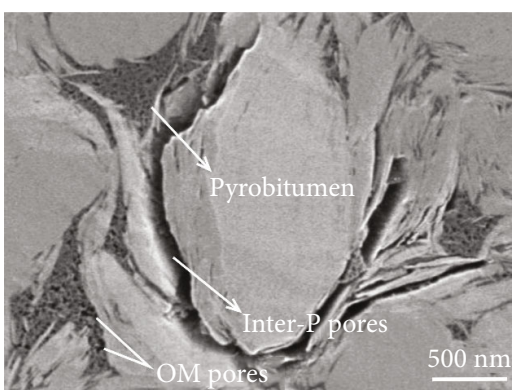

(f)

FIgURE 8: A large number of OM pores in the pyrobitumen of the Niutitang shale samples in Jingyan (JinYe1 well, $3296.2 \mathrm{~m}$ ) are shown.

In contrast, for the Jingyan study area, the maximum paleoburial depth of the Niutitang shale is $6200 \mathrm{~m}$ [4], corresponding to an Eq- $R_{\mathrm{o}}$ of $2.2 \%$ to $2.8 \%$ (Figure 11 ).

The maximum paleoburial depth of the Niutitang shale seems to be closely related to the paleostructure of the Jingyan area, which is structurally located on the wing of the Chuanzhong anticline (Figure 4). Due to the presence of the Chuanzhong paleouplift, the maximum ancient burial depth of the Niutitang shale in Jingyan is much shallower than its equivalents in south China. In contrast, the maxi- mum paleoburial depth of the Niutitang shale in Chongqing reaches $8000 \mathrm{~m}$ due to a lack of such a paleouplift, and the Eq- $R_{\mathrm{o}}$ of the Niutitang shale thus reaches a stage of overmaturity due to metamorphism $[26,39]$.

\subsection{Comparison of the Niutitang Formation in Other Areas}

5.2.1. Niutitang Shale in Yichang, Western Hubei. The Yichang area is located in the center of the Middle Yangtze Platform, and it is mainly comprised of the Huangling 


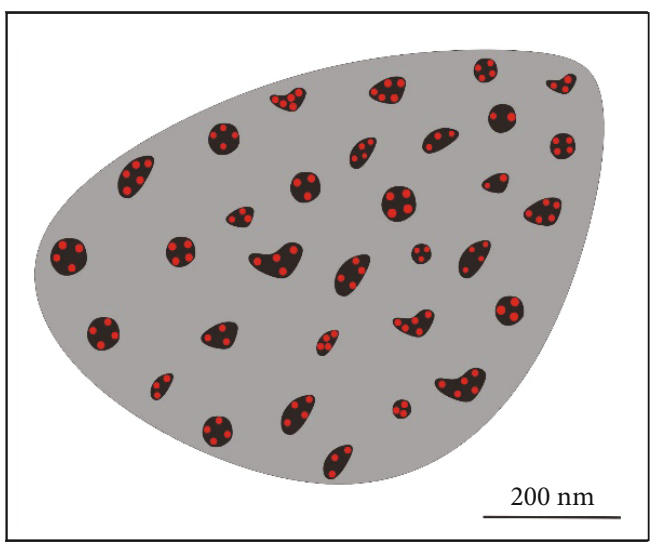

Niutitang shale in Yichang and Jingyan

(a)

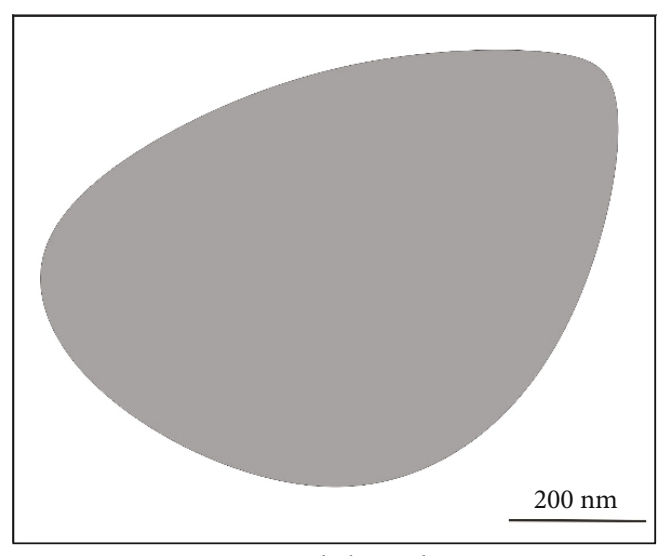

Niutitang shale in Chongqing

(b)
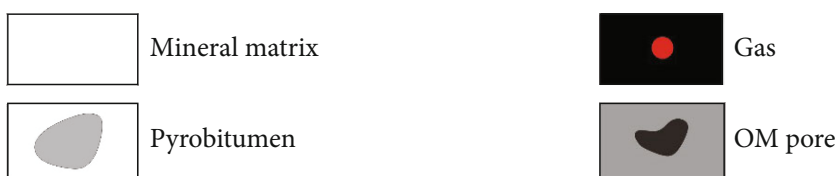

Figure 9: Gas adsorption models in different OM pore structures. (a) Based on the large number of OM pores, abundant gas was adsorbed in Jingyan shale samples. (b) No gas was adsorbed in Chongqing shale samples because there were no OM pores.

TABLE 2: Geological and reservoir development parameters with different gas contents and production of the Niutitang shale in Chongqing, Jingyan, Yichang, and Southern Guizhou. Parts of this table are revised from Refs. [2, 5, 7].

\begin{tabular}{|c|c|c|c|c|c|c|c|c|c|}
\hline Formation & Area & Well & $\begin{array}{l}\mathrm{TOC} \\
(\%)\end{array}$ & $\begin{array}{c}\mathrm{Eq}-R_{\mathrm{o}} \\
(\%)\end{array}$ & $\begin{array}{l}\text { Kerogern } \\
\text { type }\end{array}$ & $\begin{array}{l}\text { Porosity } \\
(\%)\end{array}$ & Pressure & $\begin{array}{l}\text { Gas content } \\
\left(\mathrm{m}^{3} / \mathrm{t}\right)\end{array}$ & $\begin{array}{l}\text { Gas test production }\left(10^{4}\right. \\
\left.\mathrm{m}^{3} / \mathrm{d}\right)\end{array}$ \\
\hline \multirow{4}{*}{ Niutitang } & Chongqing & CQ2 & 2.82 & 3.74 & I & 0.16 & 0.7 & 0.18 & 0 \\
\hline & Jingyan & JinYe1 & 2.36 & 2.79 & I & 3.94 & 1.38 & 2.02 & $10.5(\mathrm{HF})$ \\
\hline & Yichang & EYY1 & 2.34 & 2.77 & I & 3.68 & 0.78 & 1.98 & 7.83 \\
\hline & Huangping & HY1 & 5.81 & 2.51 & I & 0.6 & 1 & 1.3 & 1 \\
\hline
\end{tabular}

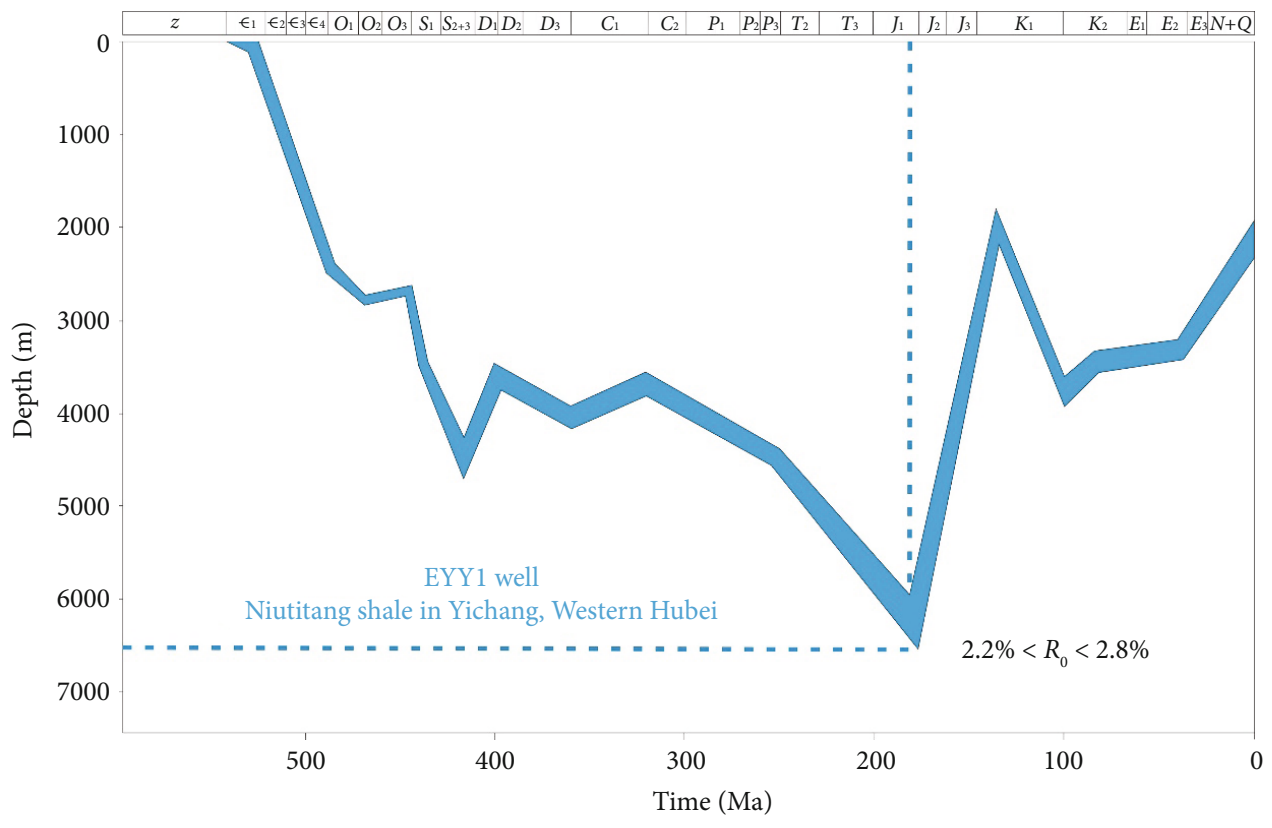

FIGURE 10: Burial history of the Niutitang shale in Yichang is based on the EYY1 well (revised from Ref. [6]). Due to the existence of the Huangling paleouplift, the ancient burial depth of the Niutitang shale distributed in its periphery is only $6500 \mathrm{~m}$. 


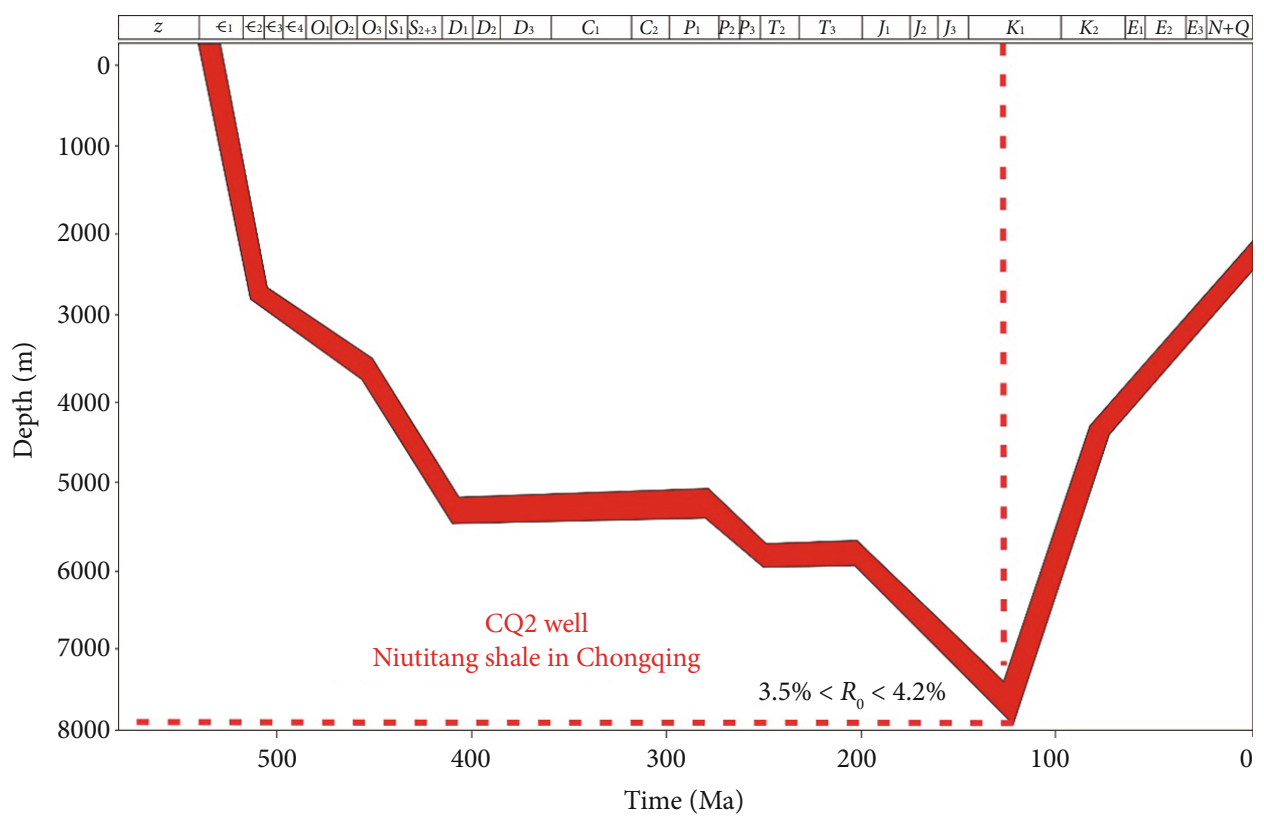

(a)

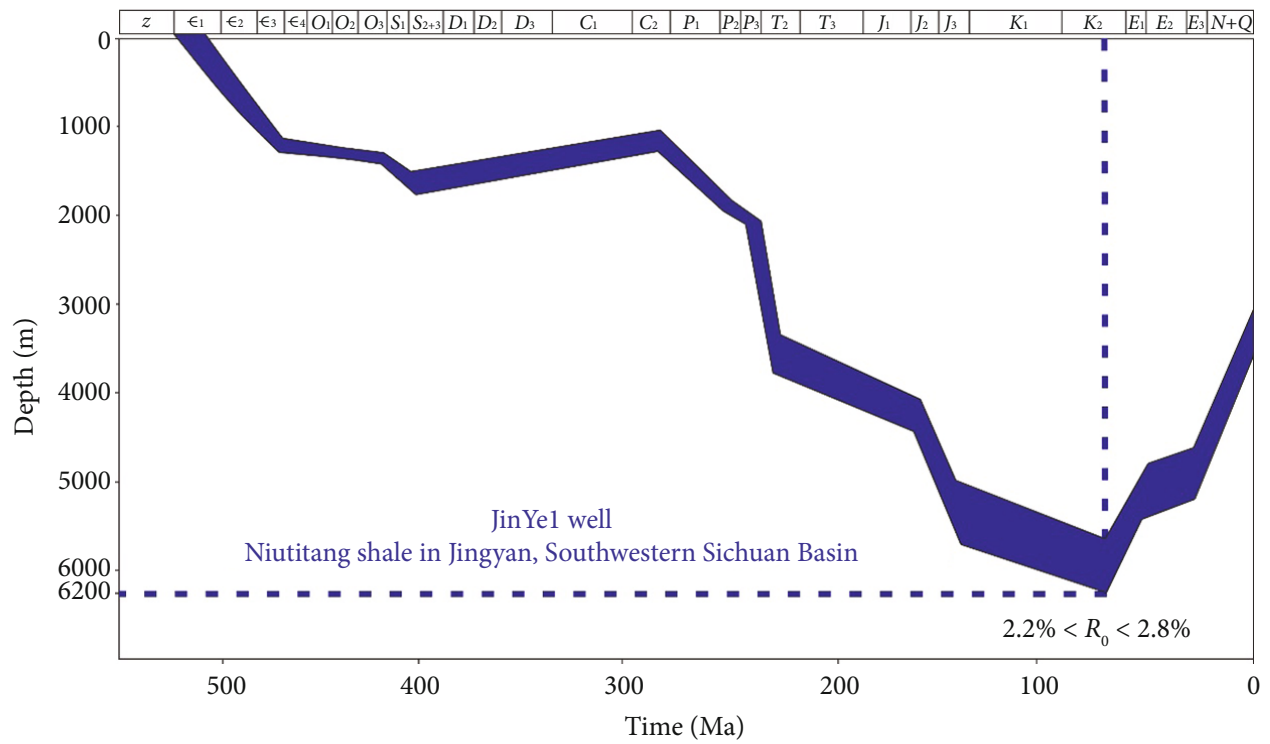

(b)

FIGURE 11: Burial history the Niutitang shale in the study area. (a) Burial history of the Niutitang shale in Chongqing based on the CQ2 well (revised from Refs. [26]). The buried depth of Chongqing reached $8000 \mathrm{~m}$. (b) Burial history of the Niutitang shale in Jingyan based on the JinYe1 well (revised from Refs. [4]). Due to the existence of Sichuan Basin margin, the ancient burial depth of the Niutitang shale distributed in its periphery was only $6200 \mathrm{~m}$.

paleouplift, the Yichang Slope Belt, the Zigui Depression, and many other tectonic units (Figure 12). At present, shale gas exploration has focused mainly on the Sinian Doushantuo Formation and the Niutitang Formation by the China Geological Survey, in the southeastern margin of the Huangling paleouplift $[33,39]$. The Huangling paleouplift was formed during the Late Jurassic to Early cretaceous with a monoclinal structure trending SE [40].

The Early Cambrian facies in the study area was developed as a result of the structuration in the Late Sinian period. Tectonic movement at the end of the Sinian led to the area as a whole forming a low section in the southwest and a high section in the northeast [5]. As a result, the Niutitang Formation thickens from the northeast to the southwest. The lithofacies of the Niutitang Formation in Yichang is gray-black and black shale mixed with marl [2]. The sediments were deposited in shallow-deep and deep shelves with a thickness of 150-240 $\mathrm{m}[6,7]$. The Niutitang Formation can be roughly divided into three sections: (i) the lower section is black shale with a thin layer of silty limestone, which is a nontypical carbonate deposit at the early stage of transgression; (ii) the middle section is gray-black and black carbonaceous shale, 


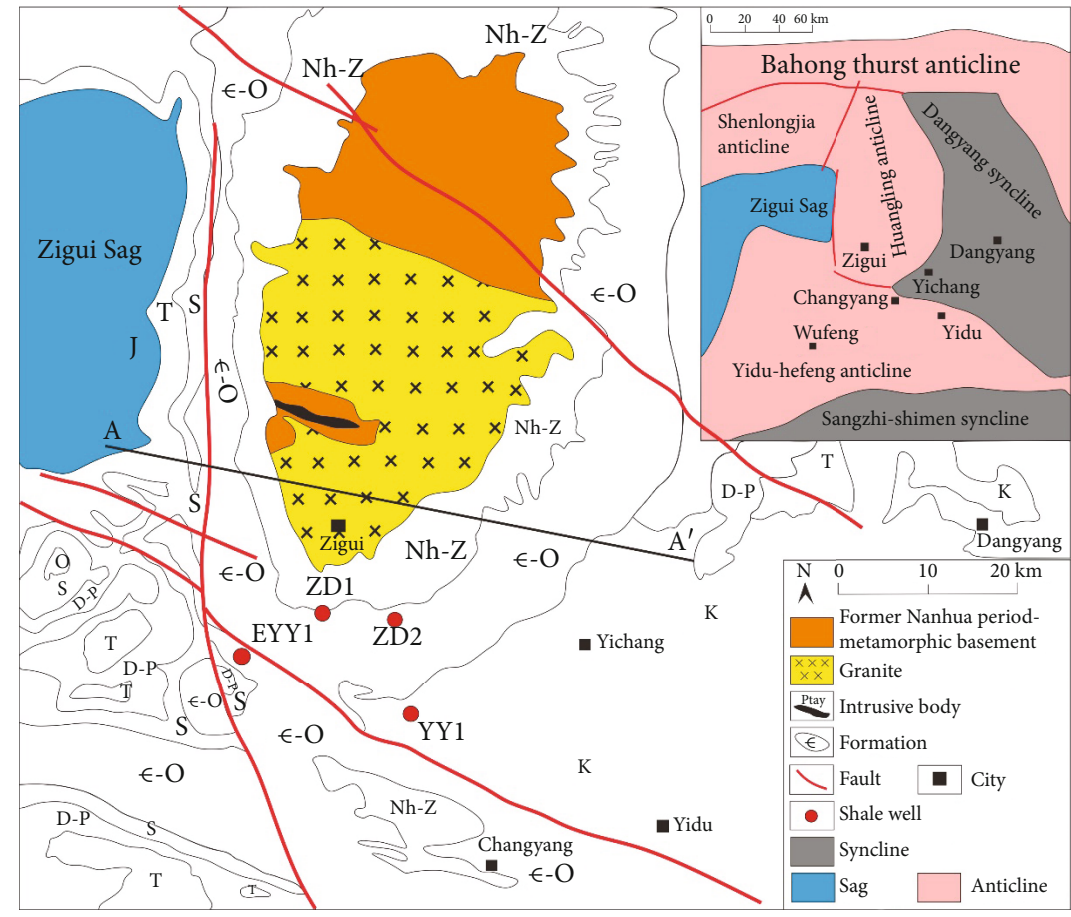

(a)

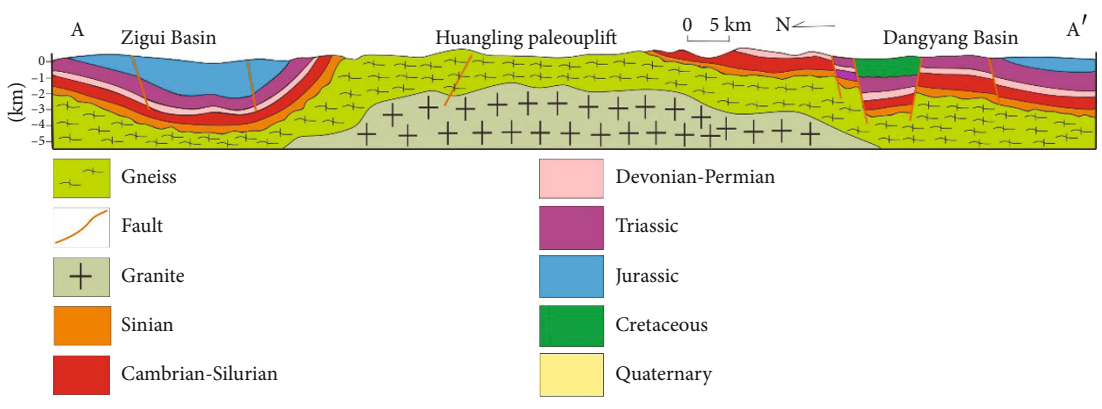

(b)

FIgURE 12: Plane and section structure of the Huangling Uplift in Hubei (revised from Refs. [5, 39]).

deposited on the outer shelf as a result of extensive transgression; and (iii) the upper section is micritic limestone which is deposited on the open platform at the high stage of transgression $[2,5,6]$. The shale with TOC $\geq 2.0 \%$ is mainly developed in the middle section of the Niutitang Formation, but with thickness variations from $9 \mathrm{~m}$ to $140 \mathrm{~m}$ [23].

TOC content of the Niutitang shale in Yichang mainly ranges between $1.2 \%$ and $4.4 \%$, with an average value of $2.3 \%[2,6,7,40]$. The Eq- $R_{\mathrm{o}}$ of the Niutitang shale in Yichang is generally below $3.0 \%$, with an average value of $2.8 \%[2,6,7]$. The Niutitang shale in Yichang is dominated by quartz, clay, and carbonate. The average quartz content is $39.3 \%$ for samples from the EYY1 well, with a range of $30.2 \%$ to $50.2 \%$. The average clay mineral content is $33.7 \%$ and has a range of $2.7 \%$ to $61.3 \%$ from samples of the YD2 well. The average carbonate mineral content is $26.2 \%$ and has a range of $8 \%$ to $39 \%$ from samples of the ZD1 well [2, 5-7].

There are a lot of OM pores inside the pyrobitumen of the Yichang shale samples. These OM pores are mostly oval and round, with a regular morphology $[2,12,15]$. For Yichang, the maximum paleoburial depth of the Niutitang shale is $6500 \mathrm{~m}$, corresponding to an Eq- $R_{\mathrm{o}}$ of $2.3 \%$ to $2.8 \%$ (Figures 13 and 10).

The maximum paleoburial depth of the Niutitang shale seems to be closely related to the paleostructure of the study area, as in the case of Yichang, which is structurally located on the wing of the Huangling paleouplift $[6,40]$. Due to the presence of the Huangling paleouplift, the maximum burial depth of the Niutitang shale in the Yichang area is much shallower than its peers. According to Figure 14 which is closer to the Huangling paleouplift, the Eq- $R_{\mathrm{o}}$ of the Niutitang shale is lower (Figure 15). The Eq- $R_{\mathrm{o}}$ average of the Niutitang shale in the ZD1 well is correspondingly $1.61 \%[2,5,7,40]$.

5.2.2. Niutitang Shale in Southern Guizhou. The Southern Guizhou area is located in the south of China, bordering the Central Guizhou Uplift in the west and adjacent to the Xuefeng Mountain Uplift in the east, the Wuling Depression in the north, and the Qiannan Depression in the south 


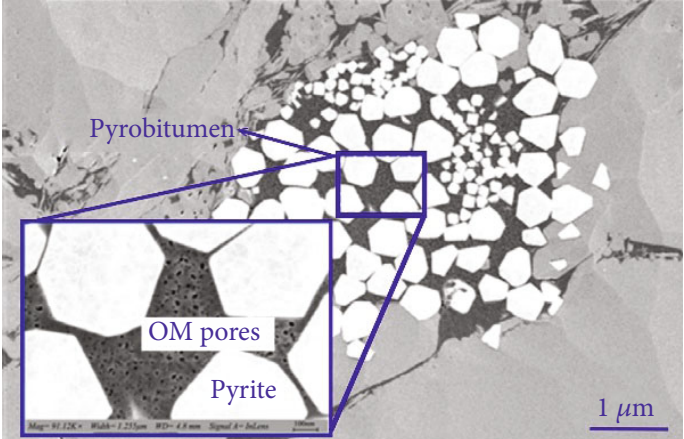

(a)

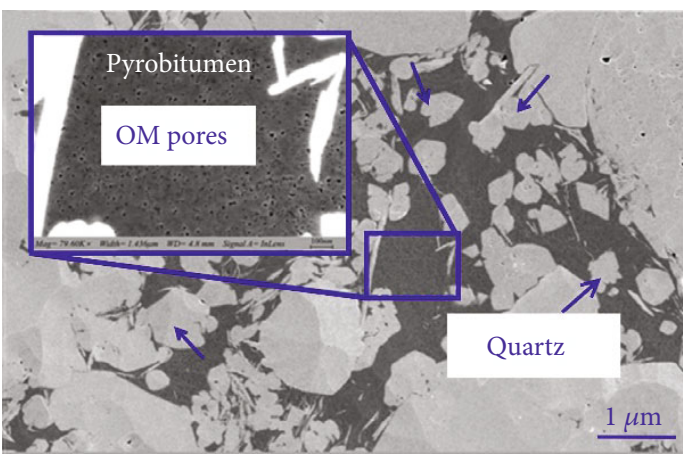

(c)

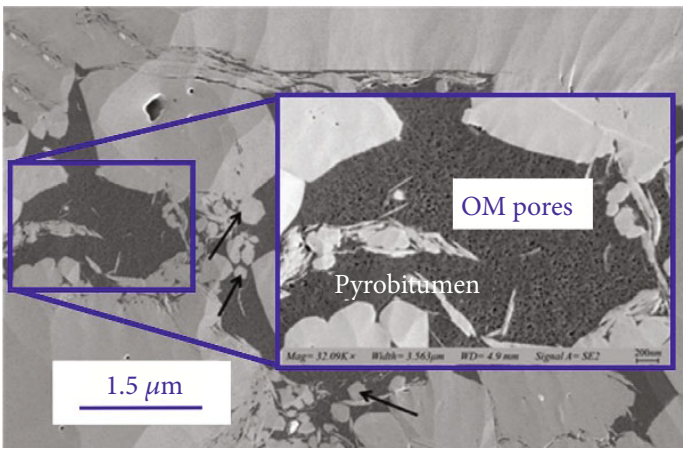

(e)

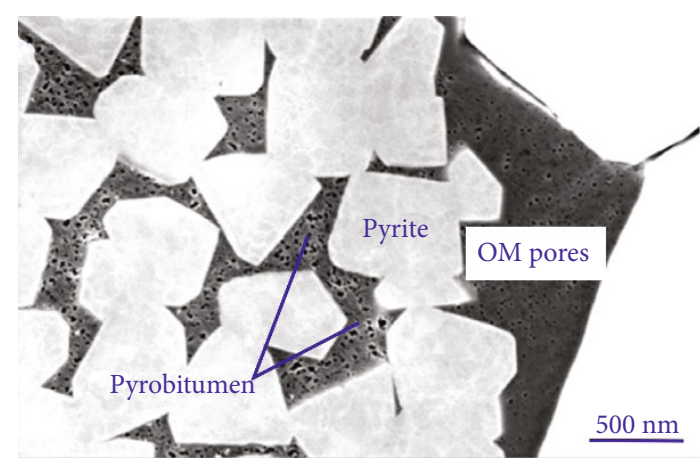

(b)

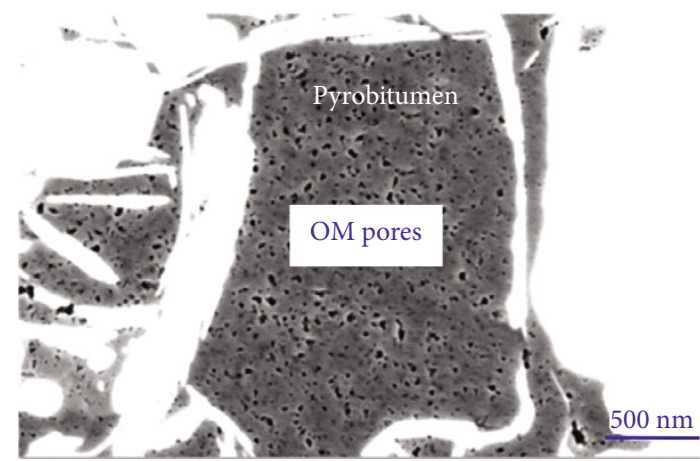

(d)

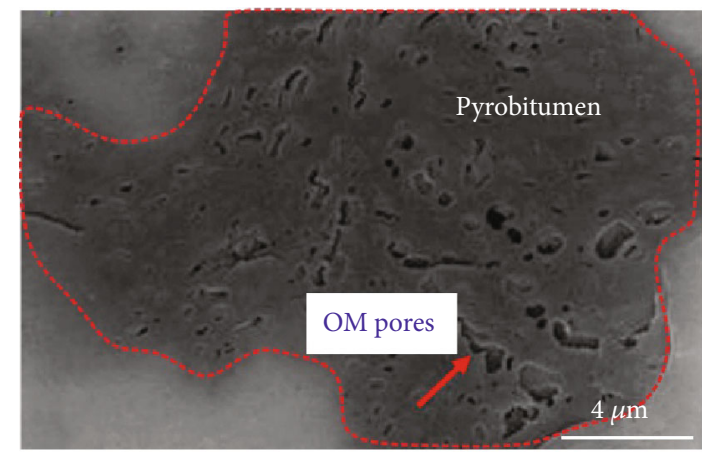

(f)

FIGURE 13: A large number of OM pores in the pyrobitumen of Yichang samples (EYY1 well, $3043 \mathrm{~m}$ ) are shown. (a, b) The pyrobitumen with OM pores in pyrite particles. (c-f) OM pores in the pyrobitumen in the mineral matrix. Parts of this figure are revised from [2, 40].

(Figure 16). In the early Paleozoic and late Paleozoic, Southern Guizhou experienced many large-scale transgression events and formed two sets of black shales representing the Cambrian, the Upper Ordovician, and the Lower Silurian $[41,42]$. The bottom of the Niutitang Formation is gray siliceous shale, the middle and lower part is gray carbonaceous shale, the upper part is dark gray argillaceous dolomite and mudstone, and the top is dark gray limestone $[43,44]$.

TOC content of the Niutitang shale in Southern Guizhou mainly ranges between $2.7 \%$ and $4.0 \%$, with an average value of $3.41 \%$ [45]. The Eq- $R_{\mathrm{o}}$ of the Niutitang shale in Southern Guizhou is generally below 3.0\%, with an average value of $2.4 \%[46,47]$. Minerals of the Niutitang shale in Southern Guizhou are also dominated by quartz, clay, and carbonate $[10,11]$.

There are a lot of OM pores inside the Southern Guizhou samples (Figure 17). These OM pores are mostly oval and round, with a regular morphology. For the Southern Guizhou, the maximum paleoburial depth of the Niutitang shale is 5600 $\mathrm{m}$, corresponding to an Eq- $R_{\mathrm{o}}$ of $2.2 \%$ to $2.7 \%$ (Figure 14 ), similar to the Yichang shale samples. The maximum paleoburial depth of the Niutitang shale seems to be closely related to the paleostructure of the Southern Guizhou area, which is structurally located on the east wing of the Qianzhong paleouplift [42, 45]. Due to the presence of the Qianzhong paleouplift, the maximum ancient burial depth of the Niutitang shale in Southern Guizhou is much shallower than its peers.

5.3. Summary. The Niutitang shale in Yichang and Guizhou has a similar thermal maturity compared with that in Jingyan. A large number of OM pores are developed in the Niutitang shale samples in Yichang and Guizhou, which is similar to the pore structure characteristics of the Niutitang 


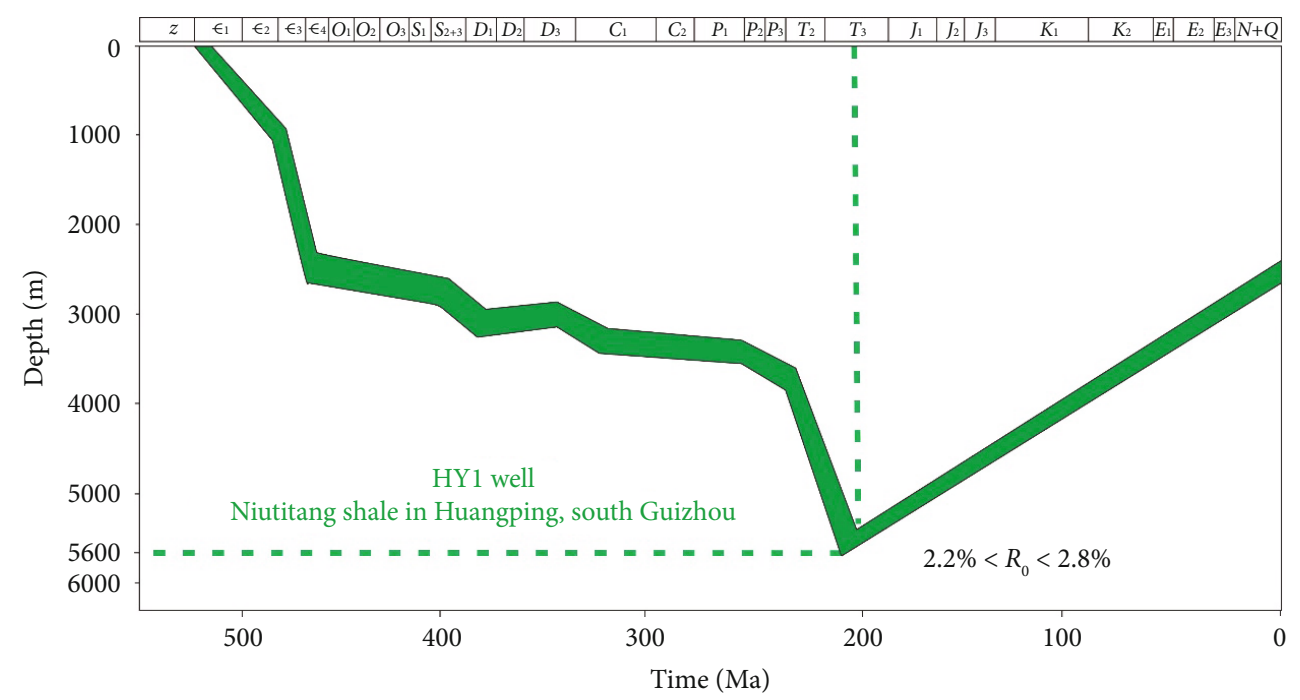

FIgURE 14: Burial history of the Niutitang shale in southern Guizhou was based on the HY1 well (revised from Ref. [9]). Due to the existence of Qianzhong paleouplift, the ancient burial depth of the Niutitang shale distributed in its periphery was only $5600 \mathrm{~m}$.

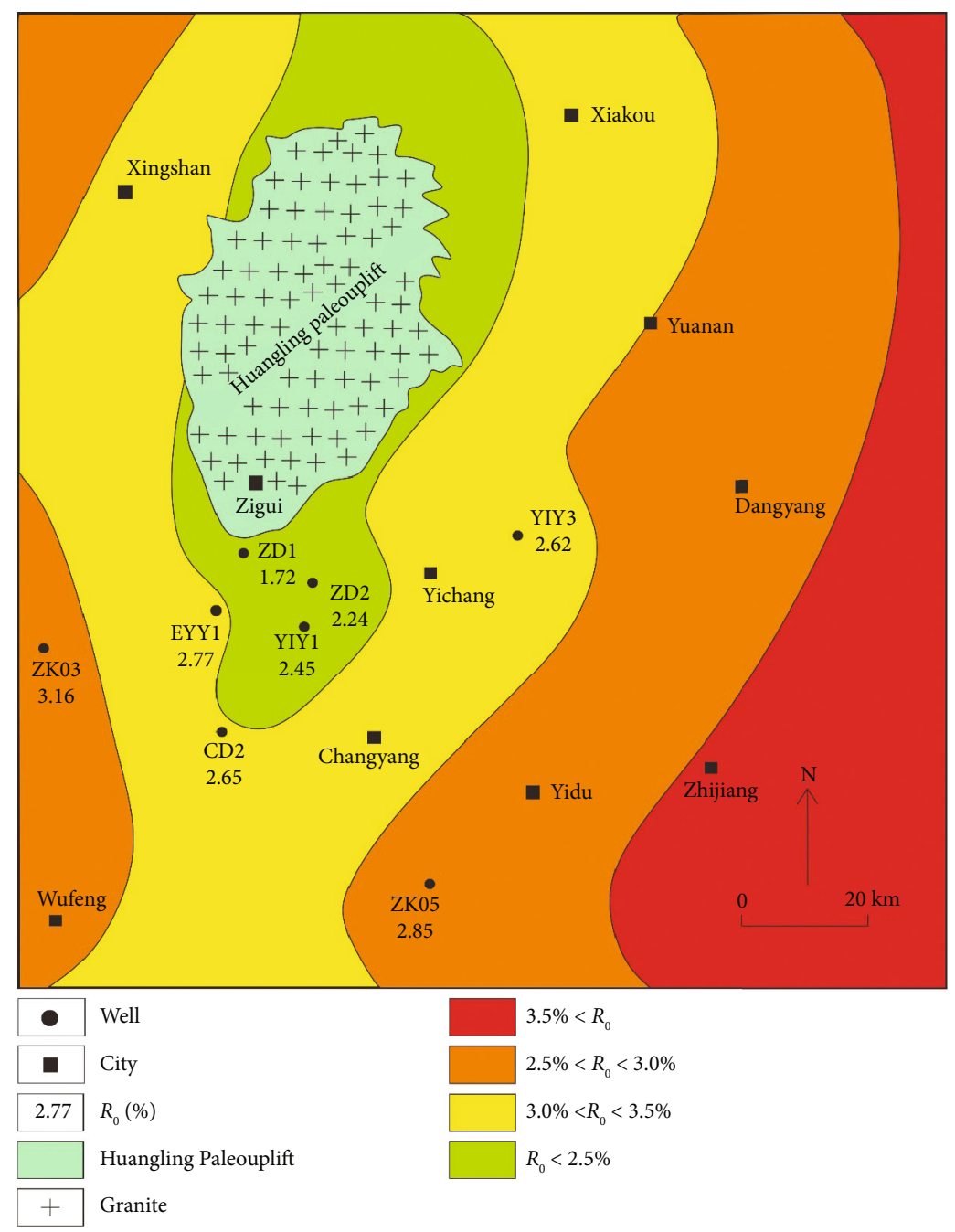

Figure 15: The Eq- $R_{\mathrm{o}}$ distribution of the Niutitang shale around the Huangling paleouplift. Due to the existence of the Huangling paleouplift, the ancient burial of the Niutitang shale is lower than those of other areas in south China. The closer to the uplift, the lower the thermal maturity of the shale. 


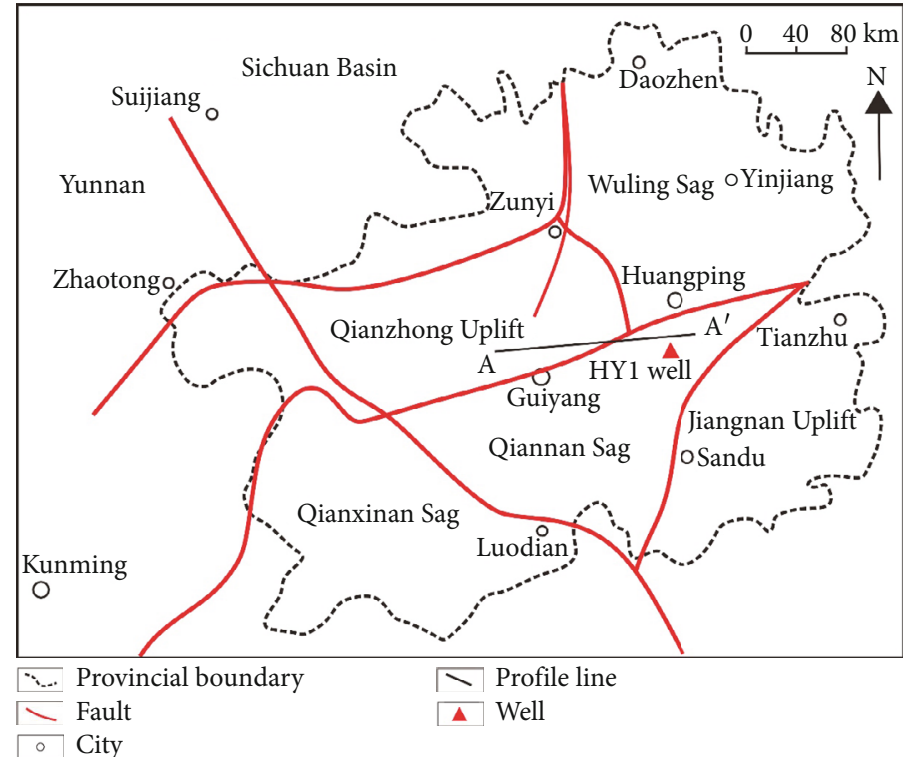

(a)

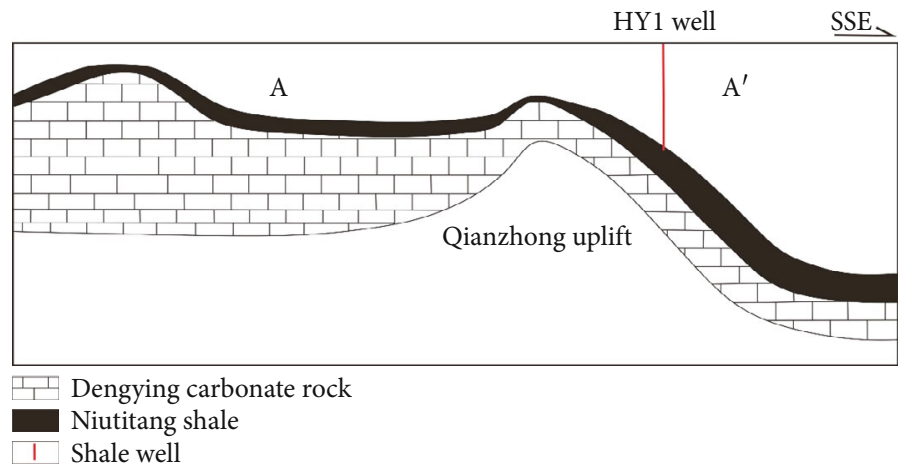

(b)

Figure 16: Plane and section structure of Qianzhong Uplift in Guizhou (revised from [41]).

shale in the Jingyan area. However, from the perspective of the Niutitang shale in Chongqing, its thermal maturity is much higher than that in the Jingyan, Yichang, and Guizhou regions, while there are no OM pores of the Niutitang shale in Chongqing. However, other parameters such as TOC content, mineral composition, and kerogen type of the Niutitang shale reservoirs in the four regions (Jingyan, Chongqing, Yichang, and Guizhou) have similar characteristics $[2,6,7$, $40,42,48-51]$. Therefore, thermal maturity is the key factor to control the OM pore development.

From the perspective of tectonic evolution, the maximum burial depth of a formation controls the thermal maturity of a shale reservoir, while the burial depth is controlled by the regional tectonic pattern $[1,4,14,32]$. According to the regional structure pattern of Jingyan, Yichang, and Guizhou, the underlying structures of the Niutitang shale are all paleouplift structures, and the target shale is distributed in the slope belt of the paleouplift $[2,4,26,33]$. Due to the existence of the paleouplift, the maximum ancient burial depth of the Niutitang shale in Jingyan, Yichang, and Guizhou is about 6000 meters $[2,4,5,10]$, and the burial depth of the shale is moderate, avoiding excessive evolution and leaving a large number of OM pores in the shale reservoir $[1,16]$. In contrast, in the Chongqing area, due to the absence of the paleouplift structure, the maximum ancient burial depth of the Niutitang shale in this area reached 8000 meters [26], and the shale reservoir experienced excessive thermal evolution, resulting in the disappearance of a large number of OM pores, and a large volume of gas was lost due to the absence of effective storage spaces in the reservoir $[49,52,53]$.

According to the successful exploration experiences of the Niutitang shale in Jingyan, Yichang, and Southern Guizhou and the failure experience of the same formation in areas like Chongqing, the exploration of the ancient marine shale reservoirs should focus on areas with moderate thermal maturity. The marine shale sedimentary in the paleouplift region has appropriate thermal maturity, so that a large number of OM pores are retained in the shale reservoir, which provides an effective space for gas occurrence, as well as a large amount of gas enrichment. Therefore, the exploration and development of marine shale with old sedimentary age (especially the lower Cambrian and older formations) should focus on the slope belt of a paleouplift (Figure 18). 


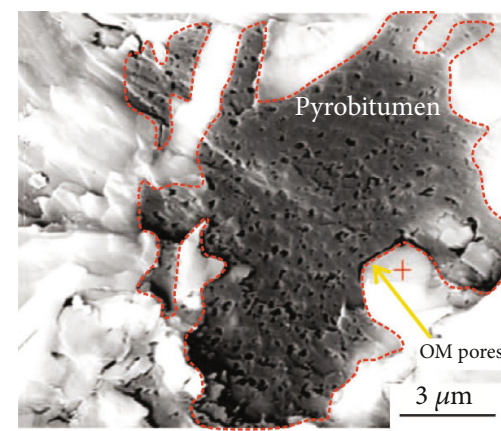

(a)

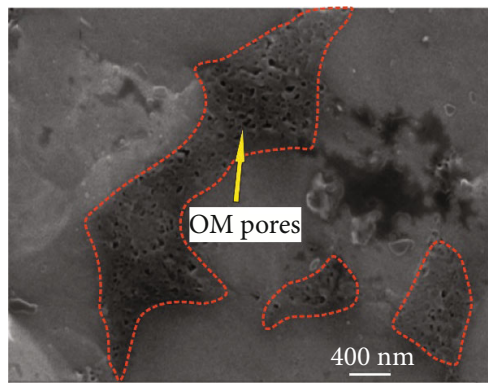

(c)

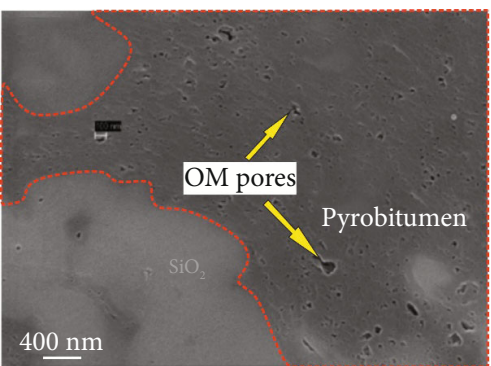

(e)

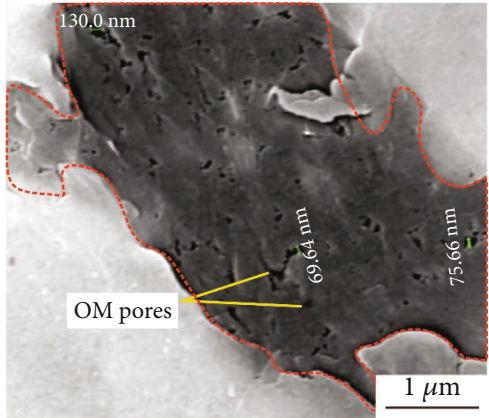

(b)

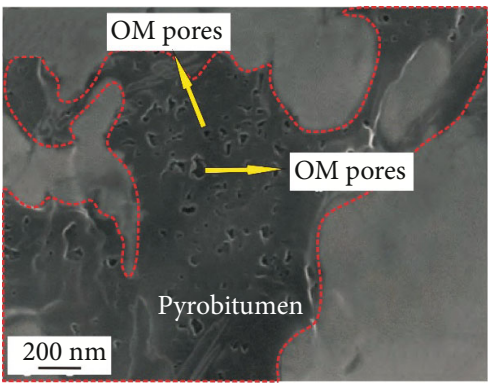

(d)

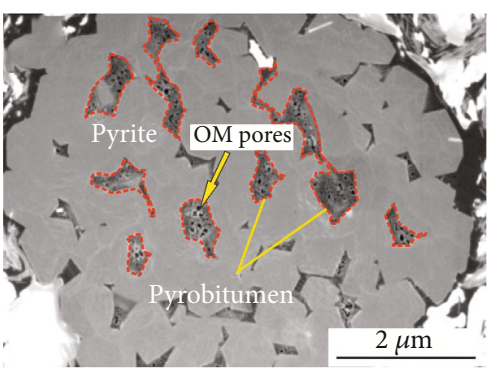

(f)

FIGURE 17: A large number of OM pores in pyrobitumen of southern Guizhou samples. (a-e) OM pores in the pyrobitumen in the mineral matrix. (f) The pyrobitumen with OM pores in pyrite particles. This figure was revised from Refs. [10, 11, 44, 46].

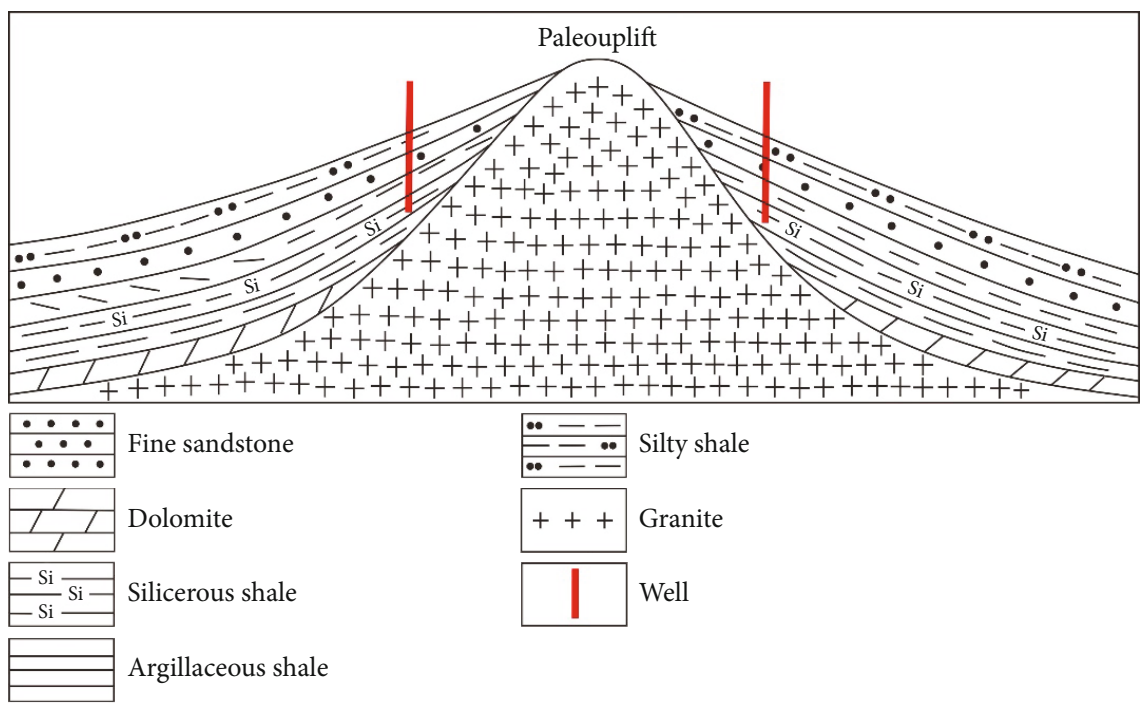

FIGURE 18: The target area for the exploration of ancient marine shale gas reservoirs. The exploration and development of ancient marine shales should focus on areas around paleouplifts. 


\section{Conclusions}

Scanning electron microscope (SEM) and geotectonic characteristics were used to illustrate organic matter (OM) pore structure and evolution in the Lower Cambrian Niutitang shale samples with different thermal maturities in northeastern Chongqing and Jingyan of the southwestern Sichuan Basin in south China. Conclusions of this study are as follows:

(1) The Niutitang shales in both Jingyan and Chongqing cities (south China) have similar TOC content (ranging from $1.5 \%$ to $3.0 \%$ ), mineral composition (dominated by silica and clays), and kerogen type (dominated by type I) but different thermal maturity. The Niutitang shale in Jingyan has a lower thermal maturity $(2.0 \%-3.0 \%)$ than that $(3.0 \%-4.0 \%)$ in Chongqing

(2) OM pore development characteristics of the Niutitang shale in Jingyan and Chongqing are quite different. The Niutitang shale in Jingyan developed a lot of large-sized $\mathrm{OM}$ pores. In contrast, almost no OM pores were found in the Niutitang shale in Chongqing. The OM pores in the Niutitang shale in Jingyan act as an effective storage of gas, contributing to gas enrichment

(3) OM pore development is mainly controlled by thermal maturity. A lot of OM pores can develop in shale reservoirs when the thermal maturity $\left(\mathrm{Eq}-R_{\mathrm{o}}\right)$ of shale is lower than $3.0 \%$. A significant amount of $\mathrm{OM}$ pores will disappear when the thermal maturity exceeds $3.0 \%$

(4) Ancient marine shales have a relatively shallow maximum burial depth when they were deposited on the slope belt of paleouplifts, which can ensure that shale reservoirs are likely not overly mature

\section{Data Availability}

All data, models, and code generated or used during the study appear in the submitted article.

\section{Conflicts of Interest}

The authors declare that they have no conflicts of interest.

\section{Authors' Contributions}

Pengfei Wang and Chen Zhang contributed equally to this work.

\section{Acknowledgments}

The authors wish to thank all those who have supplied us with original geological data. Also, the authors thank the China Geological Survey programs (Nos. DD20190414 and $121201229000160021)$ for supporting this work. The authors would also like to thank Enago (http://www.enago.cn/) for the English language review. This work was financially supported by grants from the National Natural Science Foundation of China (No. 42002050), the China Postdoctoral Science Foundation funded project (No. 2020M680815), and the Youth Natural Science Foundation of Hebei province (No. 2019403190.)

\section{References}

[1] W. Zhao, J. Li, T. Yang, S. Wang, and J. Huang, "Geological difference and its significance of marine shale gases in South China," Petroleum Exploration and Devlopment, vol. 43, no. 4, pp. 547-559, 2016.

[2] G. Zhai, Y. Wang, G. Liu et al., "The Sinian-Cambrian formation shale gas exploration and practice in southern margin of Huangling paleo-uplift," Marine and Petroleum Geology, vol. 109, pp. 419-433, 2019.

[3] Z. Xi, S. Tang, and J. Wang, "The reservoir characterization and shale gas potential of the Niutitang formation: case study of the SY well in northwest Hunan Province, South China," Journal Petroleum Science and Engineering, vol. 171, pp. 687703, 2018

[4] J. Zhao, Z. Jin, Q. Hu et al., "Geological controls on the accumulation of shale gas: a case study of the early Cambrian shale in the Upper Yangtze area," Marine and Petroleum Geology, vol. 107, pp. 423-437, 2019.

[5] J. Zhang, G. Zhai, D. Wang et al., "Tectonic evolution of the Huangling dome and its control effect on shale gas preservation in the north margin of the Yangtze Block, South China," China Geology, vol. 3, no. 1, pp. 28-37, 2020.

[6] S. Bao, G. Zhai, Z. Zhou et al., "The evolution of the Huangling uplift and its control on the accumulation and preservation of shale gas," China Geology, vol. 3, pp. 346-353, 2018.

[7] G. Zhai, J. Li, Y. Jiao et al., "Applications of chemostratigraphy in a characterization of shale gas sedimentary Microfacies and predictions of sweet spots-taking the Cambrian black shales in Western Hubei as an example," Marine and Petroleum Geology, vol. 109, pp. 547-560, 2019.

[8] W. Yang, S. He, S. Iglauer et al., "Porosity characteristics of different lithofacies in marine shale: a case study of Neoproterozoic Sinian Doushantuo formation in Yichang area, China," Journal Petroleum Science and Engineering, vol. 187, p. 106856, 2020.

[9] F. Chen, S. Lu, and X. Ding, "Gas generation period and quantity of organic-rich Niutitang Shale in Qiannan Depression, China," Journal of China University of Petroleum, vol. 40, no. 3, pp. 55-62, 2016.

[10] W. Sun, Y. Zuo, S. Wang et al., "Pore structures of shale cores in different tectonic locations in the complex tectonic region: a case study of the Niutitang formation in Northern Guizhou, Southwest China," Journal of Nature Gas Science and Engineering, vol. 80, p. 103398, 2020.

[11] W. Zeng, W. Ding, J. Zhang, Y. Li, R. Wang, and K. Jiu, "Analyses of the characteristics and main controlling factors for the micro/nanopores in Niutitang shale from China's southeastern Chongqing and northern Guizhou regions," Earth Science Frontiers, vol. 26, no. 3, pp. 220-235, 2019.

[12] R. Loucks, R. Reed, M. Ruppel, and U. Hammes, "Spectrum of pore types and networks in mudrocks and a descriptive classification for matrix-related mudrock pores," AAPG Bulletin, vol. 96, no. 6, pp. 1071-1098, 2012. 
[13] K. Milliken, M. Rudnicki, D. Awwiller, and T. Zhang, "Organic matter-hosted pore system, Marcellus formation (Devonian), Pennsylvania," AAPG Bulletin, vol. 97, no. 2, pp. 177-200, 2013.

[14] X. Guo, D. Hu, Y. Li, Z. Wei, X. Wei, and Z. Liu, "Geological factors controlling shale gas enrichment and high production in Fuling shale gas field," Petroleum Exploration and Devlopment, vol. 44, no. 4, pp. 513-523, 2017.

[15] H. Hu, F. Hao, J. Lin, Y. Lu, Y. Ma, and Q. Li, "Organic matterhosted pore system in the Wufeng-Longmaxi $\left(\mathrm{O}_{3} \mathrm{~W}-\mathrm{S}_{1} 1\right)$ shale, Jiaoshiba area, Eastern Sichuan Basin, China," International Journal of Coal Geology, vol. 173, pp. 40-50, 2017.

[16] Y. Hou, K. Zhang, F. Wang et al., "Structural evolution of organic matter and implications for graphitization in overmature marine shales, south China," Marine and Petroleum Geology, vol. 109, pp. 304-316, 2019.

[17] Q. Chen, Y. Kang, L. You, P. Yang, X. Zhang, and Q. Cheng, "Change in composition and pore structure of Longmaxi black shale during oxidative dissolution," International Journal of Coal Geology, vol. 172, pp. 95-111, 2017.

[18] W. Ji, Y. Song, Z. Rui, M. Meng, and H. Huang, "Pore characterization of isolated organic matter from high matured gas shale reservoir," International Journal of Coal Geology, vol. 174, pp. 31-40, 2017.

[19] R. Loucks and R. Reed, "Scanning-electron-microscope petrographic evidence for distinguishing organic-matter pores associated with depositional organic matter versus migrated organic matter in mudrock," Gulf Coast Associate Geology Society Journal, vol. 3, pp. 51-60, 2014.

[20] P. Wang, Z. Jiang, L. Chen et al., "Pore structure characterization for the Longmaxi and Niutitang shales in the Upper Yangtze Platform, South China: evidence from focused ion beamHe ion microscopy, nano-computerized tomography and gas adsorption analysis," Marine and Petroleum Geology, vol. 77, pp. 1323-1337, 2016.

[21] P. Wang, Z. Jiang, W. Ji et al., "Heterogeneity of intergranular, intraparticle and organic pores in Longmaxi shale in Sichuan Basin, South China: evidence from SEM digital images and fractal and multifractal geometries," Marine and Petroleum Geology, vol. 72, pp. 122-138, 2016.

[22] R. Loucks, R. Reed, S. Ruppel, and D. Jarvie, "Morphology, genesis, and distribution of nanometer-scale pores in siliceous mudstones of the Mississippian Barnett shale," Journal of Sedimentary Research, vol. 79, no. 12, pp. 848-861, 2009.

[23] K. Ma, Y. Lu, X. Liu, G. Zhai, Y. Wang, and C. Zhang, "Depositional environment and organic matter enrichment of the lower Cambrian Niutitang shale in western Hubei Province of the middle Yangtze Block, south China," Marine and Petroleum Geology, vol. 109, pp. 381-393, 2019.

[24] Q. Wang, T. Wang, W. Liu et al., "Relationships among composition, porosity and permeability of Longmaxi shale reservoir in the Weiyuan Block, Sichuan Basin, China," Marine and Petroleum Geology, vol. 102, pp. 33-47, 2019.

[25] W. Wang, X. Pang, Z. Chen et al., "Statistical evaluation and calibration of model predictions of the oil and gas field distributions in superimposed basins: a case study of the Cambrian Longwangmiao formation in the Sichuan Basin, China," Marine and Petroleum Geology, vol. 106, pp. 42-61, 2019.

[26] P. Wang, Z. Jiang, B. Han et al., "Reservoir characteristics and controlling factor of shale gas in Lower Cambrian Niutitang
Formation, South China," Petroleum Research, vol. 3, pp. 210-220, 2018.

[27] W. Yang, R. Zuo, Z. Jiang et al., "Effect of lithofacies on pore structure and new insights into pore-preserving mechanisms of the over-mature Qiongzhusi marine shales in Lower Cambrian of the southern Sichuan Basin, China," Marine and Petroleum Geology, vol. 98, pp. 746-762, 2018.

[28] J. Zhao, Z. Jin, Z. Jin et al., "Mineral types and organic matters of the Ordovician-Silurian Wufeng and Longmaxi shale in the Sichuan Basin, China: implications for pore systems, diagenetic pathways, and reservoir quality in fine-grained sedimentary rocks," Marine and Petroleum Geology, vol. 86, pp. 655674, 2017.

[29] H. Nie, C. Sun, G. Liu, W. Du, and Z. He, "Dissolution pore types of the Wufeng Formation and the Longmaxi Formation in the Sichuan basin, south China: implications for shale gas enrichment," Marine and Petroleum Geology, vol. 101, pp. 243-251, 2019.

[30] H. Nie, D. Li, G. Liu et al., "An overview of the geology and production of the Fuling shale gas field, Sichuan basin, China," Energy Geoscience, vol. 1, no. 3-4, pp. 147-164, 2020.

[31] Q. Xu, N. Qiu, W. Liu, A. Shen, and X. Wang, "Thermal evolution and maturation of Sinian and Cambrian source rocks in the central Sichuan basin, southwest China," Journal of Asian Earth Sciences, vol. 164, pp. 143-158, 2018.

[32] S. Xu, R. Liu, F. Hao et al., "Complex rotation of maximum horizontal stress in the Wufeng-Longmaxi shale on the eastern margin of the Sichuan Basin, China: implications for predicting natural fractures," Marine and Petroleum Geology, vol. 109, pp. 519-529, 2019.

[33] Q. Zhang, R. Littke, L. Zieger, M. Shabani, X. Tang, and J. Zhang, "Ediacaran, Cambrian, Ordovician, Silurian and Permian shales of the upper Yangtze platform, south China: deposition, thermal maturity and shale gas potential," International Journal of Coal Geology, vol. 216, p. 103281, 2019.

[34] L. Zhou, Z. Kang, Z. Wang, Y. Peng, and H. Xiao, "Sedimentary geochemical investigation for paleoenvironment of the Lower Cambrian Niutitang Formation shales in the Yangtze Platform," Journal Petroleum Science and Engineering, vol. 159, pp. 376-386, 2017.

[35] X. Li, Z. Jiang, P. Wang et al., "Porosity-preserving mechanisms of marine shale in Lower Cambrian of Sichuan Basin, South China," Journal of Nature Gas Science and Engineering, vol. 55, pp. 191-205, 2018.

[36] P. Wang, S. Yao, C. Jin et al., "Key reservoir parameter for effective exploration and development of high-over matured marine shales: a case study from the Cambrian Niutitang formation and the Silurian Longmaxi formation, south China," Marine and Petroleum Geology, vol. 121, p. 104619, 2020.

[37] Y. Wang, L. Wang, J. Wang, Z. Jiang, C. Jin, and Y. Wang, "Characterization of organic matter pores in typical marine and terrestrial shales, China," Journal of Nature Gas Science and Engineering, vol. 49, pp. 56-65, 2018.

[38] Z. Lan, X. Li, X. Chu et al., "SIMS U-Pb zircon ages and NiMo-PGE geochemistry of the lower Cambrian Niutitang Formation in South China: constraints on Ni-Mo-PGE mineralization and stratigraphic correlations," Journal of Asian Earth Sciences, vol. 137, pp. 141-162, 2017.

[39] S. Luo, X. Chen, A. Liu, and H. Li, "Geochemical features and genesis of shale gas from the Lower Cambrian Shuijingtuo Formation shale in Yichang block, Middle Yangtze region," Oil \& Gas Geology, vol. 40, no. 5, pp. 999-1010, 2019. 
[40] P. Zhang, "Peculiar accumulation conditions for shale gas in the Lower Cambrian in Qianzhong uplift and its periphery," Petroleum Geology Experiment, vol. 39, no. 2, pp. 162-179, 2017.

[41] S. Wei, S. He, Z. Pan et al., "Characteristics and evolution of pyrobitumen-hosted pores of the overmature Lower Cambrian Shuijingtuo shale in the south of Huangling anticline, Yichang area, China: evidence from FE-SEM petrography," Marine and Petroleum Geology, vol. 116, p. 104303, 2020.

[42] W. Sun, Y. Zuo, Z. Wu et al., "Pore characteristics and evolution mechanism of shale in a complex tectonic area: case study of the Lower Cambrian Niutitang Formation in Northern Guizhou, Southwest China," Journal Petroleum Science and Engineering, vol. 193, p. 107373, 2020.

[43] F. Shang, Y. Zhu, Q. Hu et al., "Characterization of methane adsorption on shale of a complex tectonic area in Northeast Guizhou, China: experimental results and geological significance," Journal of Nature Gas Science and Engineering, vol. 84, p. 103676, 2020.

[44] Z. Liu, B. Gao, Z. Hu, W. Du, H. Nie, and T. Jiang, "Pore characteristics and formation mechanism of high-maturity organic-rich shale in lower Cambrian Jiumenchong Formation, southern Guizhou," Petroleum Research, vol. 3, no. 1, pp. 57-65, 2018.

[45] Q. Gou, S. Xu, F. Hao et al., "Full-scale pores and microfractures characterization using FE-SEM, gas adsorption, nano-CT and micro-CT: a case study of the Silurian Longmaxi Formation shale in the Fuling area, Sichuan Basin, China," Fuel, vol. 253, pp. 167-179, 2019.

[46] X. Li, Z. Shen, W. Li, and H. Huang, "Exploration and development potential of Niutitang Fm shale gas in Fenggang area, North Guizhou," Nature Gas Industry, vol. 36, no. 12, pp. 72-79, 2016.

[47] Z. Li, J. Zhang, D. Dong et al., "Gas-bearing property of the Lower Cambrian Niutitang Formation shale and its influencing factors: a case study from the Cengong block, northern Guizhou Province, South China," Marine and Petroleum Geology, vol. 120, p. 104556, 2020.

[48] K. Zhang, C. Jia, Y. Song et al., "Analysis of Lower Cambrian shale gas composition, source and accumulation pattern in different tectonic backgrounds: a case study of Weiyuan Block in the Upper Yangtze region and Xiuwu Basin in the Lower Yangtze region," Fuel, vol. 263, pp. 1-15, 2020.

[49] K. Zhang, J. Peng, W. Liu et al., "The role of deep geofluids in the enrichment of sedimentary organic matter: a case study of the Late Ordovician-Early Silurian in the upper Yangtze region and early Cambrian in the lower Yangtze region, south China," Geofluids, vol. 2020, Article ID 8868638, 12 pages, 2020.

[50] K. Zhang, J. Peng, X. Wang et al., "Effect of organic maturity on shale gas genesis and pores development: a case study on marine shale in the upper Yangtze region, South China," Open Geoscience, vol. 12, no. 1, pp. 1617-1629, 2020.

[51] S. Xu, Q. Gou, F. Hao, B. Zhang, Z. Shu, and Y. Zhang, "Multiscale faults and fractures characterization and their effects on shale gas accumulation in the Jiaoshiba area, Sichuan Basin,
China," Journal of Petroleum Science and Engineering, vol. 189, p. 107026, 2020.

[52] Z. Liu, B. Gao, Y. Zhang, W. Du, D. Feng, and H. Nie, “Types and distribution of the shale sedimentary facies of the Lower Cambrian in Upper Yangtze area, South China," Petroleum Exploration Development, vol. 44, no. 1, pp. 20-31, 2017.

[53] A. Li, W. Ding, K. Jiu, Z. Wang, R. Wang, and J. He, "Investigation of the pore structures and fractal characteristics of marine shale reservoirs using NMR experiments and image analyses: a case study of the lower Cambrian Niutitang Formation in northern Guizhou province, south China," Marine and Petroleum Geology, vol. 89, pp. 530-540, 2018. 